\title{
The underpricing of IPOs on the stock exchange of Mauritius
}

Article

Accepted Version

Agathee, U. S., Sannassee, R. V. and Brooks, C. (2012) The underpricing of IPOs on the stock exchange of Mauritius.

Research in International Business and Finance, 26. pp. 281303. ISSN 0275-5319 doi:

https://doi.org/10.1016/j.ribaf.2012.01.001 Available at https://centaur.reading.ac.uk/26244/

It is advisable to refer to the publisher's version if you intend to cite from the work. See Guidance on citing.

To link to this article DOI: http://dx.doi.org/10.1016/j.ribaf.2012.01.001

Publisher: Elsevier

All outputs in CentAUR are protected by Intellectual Property Rights law, including copyright law. Copyright and IPR is retained by the creators or other copyright holders. Terms and conditions for use of this material are defined in the End User Agreement.

\section{www.reading.ac.uk/centaur}

\section{CentAUR}

Central Archive at the University of Reading 
Reading's research outputs online 
NOTICE: this is the author's version of a work that was accepted for publication in Research in International Business and Finance. Changes resulting from the publishing process, such as peer review, editing, corrections, structural formatting, and other quality control mechanisms may not be reflected in this document. Changes may have been made to this work since it was submitted for publication. A definitive version was subsequently published in Research in International Business and Finance, 26.2 (2012), DOI: 10.1016/j.ribaf.2012.01.001 $€$ 


\title{
The Underpricing of IPOs on the Stock Exchange of Mauritius
}

\author{
Ushad Subadar Agathee \\ Department of Finance and Accounting, \\ Faculty of Law and Management, \\ University of Mauritius. \\ Email: u.subadar@uom.ac.mu \\ Raja Vinesh Sannassee \\ Department of Finance and Accounting, \\ Faculty of Law and Management, \\ University of Mauritius. \\ Email: rvsan@uom.ac.mu \\ Chris Brooks* \\ ICMA Centre \\ University Of Reading \\ Email: c.brooks@icmacentre.reading.ac.uk
}

\begin{abstract}
This paper investigates the underpricing of IPOs on the Stock Exchange of Mauritius (SEM). Taking into account the whole population of firms which went public since the inception of the SEM until 2010, the results show an average degree of underpricing within the range 10 to $20 \%$. Using a regression approach, we demonstrate that the aftermarket risk level and auditor's reputation both have a significant positive impact on initial returns. We propose the use of the Z-score as a composite measure of a firm's ex ante financial strength, and find that it has a significant negative effect on the degree of short-run underpricing.
\end{abstract}

Keywords: Initial Public Offerings, Underpricing; Ex ante Uncertainty hypothesis; Underwriter Reputation Hypothesis; Stock Exchange of Mauritius

* Corresponding author: Chris Brooks, ICMA Centre, University of Reading, Whiteknights, Reading RG6 6BA, UK. 


\section{Introduction}

Undoubtedly, initial public offerings (IPOs) have generated an enormous amount of public interest and are one of the most researched areas in finance. Common empiricisms have shown that IPOs are subject to three well documented anomalies, namely, the shortrun underpricing of IPOs, the hot issue market phenomenon and the long-run performance of IPOs. With regard to short-run underpricing, issuers offer shares to investors at prices considerably below the subsequently revealed market value. The underpricing of IPOs is anomalous in the sense that it appears to contradict the efficient markets hypothesis. In particular, one would expect the underpricing of IPOs to disappear over time as the overwhelming majority of investors will recognise the implied profit opportunities and make good use of them. However, the underpricing of IPOs seems to be persistent in most markets. Also, it would be difficult to rationally justify the behaviour of existing owners to sell shares to outsiders at discounted prices. The fact that these anomalies exist in numerous developed and developing markets makes them even more difficult to explain.

There are a number of theoretical explanations and models underpinning this IPO underpricing. The popular justifications for this observed phenomenon rest upon the possible existence of information asymmetries, mainly in the form of ex ante uncertainties about share prices. ${ }^{1}$ Also, according to Welch (1989), Grinblatt and Hwang (1989), and other similar studies, ${ }^{2}$ there exists a signalling mechanism where firms send signals to the market by underpricing their IPOs. Moreover, there are other possible explanations such as underwriter reputation theories, investor sentiment theories and prospect theories to explain the degree of underpricing in the IPO market.

However, there are still gaps in the literature as most studies have focused on the developed and well known developing markets. Essentially, the newness of the Mauritian market, the relative lack of investor sophistication and the distinct institutional features make the Stock Exchange of Mauritius (SEM) a unique environment in which to conduct

\footnotetext{
${ }^{1}$ Rock (1986), Ritter (1984), Ritter (1991), Garfinkel (1993), Ljungqvist and Wilhelm (2003), and Adjasi et al. (2011) amongst others.

2 For example, Leland and Pyle (1977), Espenlaub and Tonks (1998), Kim et al. (2004), Habib and Ljungqvist (2001), Francis and Hasan (2001), and Loughran and Ritter (1995; 2002).
} 
research. Additionally, very little research has conducted with regard to IPOs in African markets and the literature is not abundant relative to that on developed markets such as the US and the UK. This may be explained by the fact that most stock exchanges ${ }^{3}$ in Africa are relatively young and indeed, most were set up in the early 1990's. In particular, there are only two previous studies that have been undertaken on Mauritian IPOs by Gasbarro et al. (2003) and Bundoo (2007), focusing on the aftermarket performance and underpricing of IPOs. However, both studies are subject to some caveats. First, the sample periods of those studies are limited. In fact, the first study only contains firms which are listed from 1989 until 1996, while the second study takes into account firms listed until 2004. Also, for both studies, some firms are not included in the sample. Second, the studies do not consider the significance of the signalling and underwriter reputation hypotheses in explaining the degree of underpricing. Third, the studies do not examine the issuing activity of seasoned equity offerings on the SEM. Fourth, the studies do not consider the motives for going public on the SEM. Given these limitations, a reassessment of the market conditions of Mauritian IPOs seems warranted. Therefore, this paper aims to fill the research gap by addressing all the limitations present in both studies. In effect, the focus of the research is to take into account all firms listed on the SEM from 1989 until 2010.

Moreover, the methodological contribution of this research is to develop a good proxy for the ex ante uncertainty of the firm in explaining the underpricing of IPOs based on the Altman Z-score model. Indeed, prior studies have focused on various proxies for ex ante uncertainty based on different accounting ratios. However, most of these accounting ratios reflect a single aspect of the firm at one time. For example, the financial leverage ratio will reflect the ex ante uncertainty of the firm by capturing only the gearing level of the company. On the other hand, the Z-score takes into account several characteristics of the firm simultaneously, namely liquidity, profitability, productivity of assets, gearing and income generating ability. To the knowledge of the authors, application of the Zscore as a proxy for ex ante uncertainty to explain the short-run underpricing of IPOs has not been considered so far in the literature.

\footnotetext{
${ }^{3}$ Based on the UNDP 2003, African Stock Market Handbook.
} 
The remainder of the paper is organised as follows. Section 2 reviews the key contributions in the literature on the underpricing of initial public offerings. Section 3 briefly describes the Stock Exchange of Mauritius and the institutional framework. Section 4 outlines the methodology employed, while the results are presented and analysed in Section 5, with Section 6 offering concluding remarks.

\section{Prior Research}

Though many studies have been conducted in different markets, the IPO market in the United States remains the most extensively examined. Overall, with a few exceptions, most studies claim an average initial return in the 10-20\% range in the US IPO markets. ${ }^{4}$ With regards to the European markets, the studies show that the average level of underpricing can be below $10 \%$ in some European countries and above $20 \%$ in other markets. ${ }^{5}$ However, compared to the European, the US markets and Latin American markets ${ }^{6}$, the average underpricing in most Asian stock markets ${ }^{7}$ is considerably higher. Yet one has to be cautious in any comparisons made across markets as consideration has to be given to the differences in sample size, time-frame and methodologies in calculating the average initial returns across the studies. Considering the African markets, the empirical evidence is limited relative to research work in other developed and emerging markets. In particular, the stock markets are relatively young. With the possible exception of South Africa, academic research on IPO issues in general is either limited or nonexistent. ${ }^{8}$

Overall, the degree of underpricing varies from country to country. Indeed, the characteristics pertaining to each market are distinct. Some markets are known to be

\footnotetext{
${ }^{4}$ See, for example, Ritter (1991), Ibbotson et al. (1994), Ritter and Welch (2002), Bommel, Dahya, and Shi (2005), Lowry et al. (2010), and Chahine and Saade (2011).

${ }^{5}$ E.g., Jelic and Briston (2003), Kazantzis and Levis (1995), Levis (1993), Ljungqvist (1997), Lyn and Zychowicz (2002), Günther and Rummer (2006), Gounopoulos, Nounis, and Stylianides (2007), Boulton et al. (2007), and Banerjee et al. (2011).

${ }^{6}$ Aggarwal et al. (1993), Brau et al. (2009)

${ }^{7}$ E.g., Kim et al. (1993), Hameed and Lim (1998), Isa and Yong (2003), Hibara and Mathew (2004), Chen, Choi, \& Jiang (2007), Chorruk and Worthington (2010), Samarakoon (2010), and Moshiran, Ng and Wu (2010).

${ }^{8}$ A few noteworthy published studies on African markets are Reyneke and Page (1997), Omran (2005), Gasbarro, Bundoo and Zumwalt (2003),Alli, Subrahmanyam and Gleason (2008) and Adjasi et al. (2011).
} 
highly sophisticated and well developed; others are termed emerging markets while a few markets will be regarded as small and underdeveloped. Prior studies in emerging markets are significant to this research given that the Mauritian market can be categorised as a relatively young and emerging market. As such, the literature in the context of emerging markets show that IPOs from the Chinese, Bangladesh and Indian markets ${ }^{9}$ seems to enjoy the highest average initial returns (more than 90\%). In particular, Jenkinson and Ljunqvist (2001) claim that these levels are higher relative to other emerging markets. However, the existing evidence of underpricing in other Asian emerging markets shows initial returns of $21.43 \%, 61.81 \%$ and $70.30 \%$ in Hong Kong, Malaysian and Korean markets respectively. ${ }^{10}$ In particular, it seems that the emerging Asian markets are experiencing a much larger degree of underpricing than markets in any other region.

\subsection{Theories and Models of Underpricing}

A simple theoretical framework integrating all factors affecting underpricing does not yet exist. Therefore, a number of competing theoretical models have been developed to explain the initial underpricing of stocks. The main theories found in the IPO literature are the Winner's Curse hypothesis, Bookbuilding theories, the Principal-Agent hypothesis, Signalling theories, the Law-suit avoidance hypothesis, the Ownership and Control hypothesis and the Investor Sentiment theory.

One of the most important models of underpricing is the one developed by Rock (1986) based on the winner's curse hypothesis. Rock distinguishes between informed and uninformed investors. If the issues are underpriced, IPOs will be oversubscribed by informed investors, resulting in a limited number of shares being available to uninformed investors. If the issues are overpriced, IPOs will be sold exclusively to uninformed investors who will earn negative initial returns. Thus, uninformed investors will be winning the entire issue but at an unfavourable price, creating a situation termed the winner's curse. In order to keep uninformed investors in the IPO market, securities are offered at a discount from their expected after market prices. Thus, according to the

\footnotetext{
${ }^{9}$ See Chen, Choi, \& Jiang (2007) for the Chinese market, Islam et al. (2010) for the Bangladesh market and Ghosh S. (2002) for the Indian market.

${ }^{10}$ Moshiran, $\mathrm{Ng}$ and $\mathrm{Wu}(2010)$.
} 
Winner's Curse theory, IPO underpricing should decrease if the information asymmetry between informed and uninformed investors is reduced. One of the most common actions to reduce underpricing is to seek assistance from a prestigious underwriter or auditor to certify the quality of the issue. ${ }^{11}$ This may decrease the number of informed investors in the market and as such, reduce the winner's curse problem. However, more recently, Hoberg (2007) and Liu and Ritter (2011) claim that prestigious underwriters will underprice more as they benefit from underpricing. In particular, Hoberg (2007) predicts that "high underpricing underwriters have access to superior information, and they use their advantage to win mandates with more valuable issuers." The empirical evidence as to whether more prestigious underwriters are associated with lower underpricing is mixed. On one hand, Carter and Manaster (1990) and Megginson and Weiss (1991), using data on the US market from the 1970s and 1980s, find a negative relationship between initial returns and underwriter reputation, whilst on the other, Beatty and Welch (1996), using data from the 1990s, claim a positive relationship. According to Loughran and Ritter (2004), the shift in this relationship may be due to a strategic decision by prestigious banks either to favour their investment clients or to weaken their criteria for selecting IPOs.

Furthermore, Beatty and Ritter (1986) extended Rock's model of underpricing to predict a positive relationship between underpricing and ex ante uncertainty. According to Beatty and Ritter (1986), the greater the ex ante uncertainty about the value of a new issue, the greater will be the associated information asymmetry, leading to higher underpricing. In line with this idea, empirical studies have employed various proxies for ex ante uncertainty. According to Ljungqvist (2006), the proxies can be loosely categorized into four groups: company characteristics, offering characteristics, prospectus disclosure, and aftermarket variables. Considering company characteristics, some studies have used age, ${ }^{12}$ firm size,${ }^{13}$ or industry. ${ }^{14}$ For instance, Beatty and Ritter (1986) predict a negative

\footnotetext{
${ }^{11}$ Booth and Smith (1986), Titman and Trueman (1986), Carter and Manaster (1990), Michaely and Shaw (1994) and Carter et al. (1998).

${ }^{12}$ Ritter (1984), Ritter (1991), Garfinkel (1993) and Ljungqvist and Wilhelm (2003), and Adjasi et al. (2011).

${ }^{13}$ Ritter (1984), Beatty and Ritter (1986), Levis (1990), and Adjasi et al. (2011).

${ }^{14}$ Benveniste, Ljungqvist, Wilhelm, and Yu (2003), and Al-Hassan et al. (2010).
} 
relationship between a firm's size and underpricing given that small firms' prices are assumed to be more volatile and uncertain. According to Beatty and Ritter (1986), the size of IPOs can be used as a proxy for ex ante uncertainty about their ex post value. The existing evidence on IPO performance suggests that a smaller issue is more likely to have greater initial underpricing followed by a worse aftermarket performance. Also, risk factors ${ }^{15}$ and uses of gross proceeds ${ }^{16}$ disclosed in the prospectus, can serve as proxies for ex ante uncertainty.

Similarly, some studies ${ }^{17}$ have focused on aftermarket variables such as volatility or trading volume. For instance, Reber and Fong (2006), using a sample of 100 Singaporean initial public offerings (IPOs) during the period 1998-2000, find a positive and significant relationship between underpricing and after-market trading volume on the first day of trading.

On the other hand, bookbuilding theories ${ }^{18}$ consider underpricing as a mechanism used by underwriters to extract private information from investors. The theory predicts higher levels of underpricing to be associated with higher levels of information asymmetry between underwriters and investors. In effect, based on the Benveniste and Spindt (1989) framework, the investment bank can provide some incentives to reveal truthful information mainly in terms of awarding the issue to investors that bid in the most aggressive way against those that bid conservatively. However, for investors to be aggressive and wanting to reveal their information, underwriters will have to 'leave money on the table,' i.e. the issues will have to be underpriced.

Moreover, the principal-agent model documents the information asymmetry between issuers and underwriters, with the latter having an expertise in marketing shares. As such, the underwriter has an incentive to underprice the shares either to reduce marketing

\footnotetext{
${ }^{15}$ Beatty and Welch (1996), and Jog and Wang (2002).

${ }^{16}$ Beatty and Ritter (1986), Islam et al. (2010), and Samarakoon (2010).

${ }^{17}$ Miller and Reilly (1987), Ritter (1984, 1987), Wasserfallen and Wittleder (1994), and Reber and Fong (2006).

${ }^{18}$ Benveniste and Spindt (1989), Hanley (1993), Cornelli and Goldreich (2003) and Jenkinson and Jones (2004).
} 
efforts or to favour some established clients. According to Loughran and Ritter (2004), there is a principal-agent problem between the issuer (principal) and the underwriter (agent) in that the agent will not always act in the best interests of the principal. To this effect, Baron (1982) argues that investment banks (underwriters) have an incentive to underprice as a way of favouring their established clients. There are mechanisms such as underwriting fees being dependent on IPO proceeds that can control the agency problem faced by issuers. However, underwriters may, at times, be rewarded more by the commissions received from underpricing the issues than by the increase in underwriting fees.

Other theoretical models posit the idea of underpricing as a signalling mechanism used by firms. Based on the signalling models developed by Welch (1989) amongst others, ${ }^{19}$ high quality firms underpriced their IPOs in order to signal their high valuations to the market. In fact, underpricing in such cases will initially bring reduced issue proceeds to the firm but will "leave a good taste in investors' mouths." ${ }^{20}$ However, given the initial good signal sent to the market, the firm will be able to make a subsequent seasoned offering at a higher price. Thus, the initial reduction in issue proceeds is assumed to be recovered in subsequent offerings. Therefore, underpricing is viewed as a signal of firm quality in the market. However, according to Allen and Faulharber (1989), underpricing is just one among several variables which can be used to signal a given firm's quality. For instance, the choice of underwriters, ${ }^{21}$ choice of auditors, ${ }^{22}$ board of directors, operating results, etc. can be used to covey information about a firm's quality

Furthermore, the lawsuit avoidance hypothesis claims that companies underprice their shares to reduce the probability of lawsuits from investors due to any omissions or errors in the prospectus. ${ }^{23}$ Ritter (1998) argues that this hypothesis is consistent with the provision of the Securities Act 1933 in the US, where omissions of significant materials can set off lawsuits. Consistent with the predictions of the lawsuit avoidance hypothesis,

\footnotetext{
${ }^{19}$ Grinblatt and Hwang (1989), Allen and Faulhaber (1989) and Ravid and Spiegel (1997).

${ }^{20}$ Ibbotson (1975).

${ }^{21}$ Booth and Smith (1986), and Corwin and Schultz (2005).

22 Titman and Trueman (1986), Beatty (1989), and Adjasi et al. (2011).

${ }^{23}$ Based on the basic idea of Logue (1973) and Ibbotson (1975).
} 
Banerjee et al. (2011) claim a positive relationship between the accessibility of legal recourse and IPO underpricing using a sample of 8,776 IPOs from 36 countries. However, according to Ljungqvist (2006), the securities laws are specific in that some countries do have strict liability laws. Yet, underpricing is observed worldwide. As such, the lawsuit hypothesis may be regarded as a second driver of underpricing. Indeed, many researchers ${ }^{24}$ have concluded that the probability of lawsuits is insignificant in markets such as Australia, Japan, Germany, the UK, Finland, etc.

In addition, Brennan and Franks (1997) consider monitoring costs as an incentive to underprice. They develop the reduced monitoring hypothesis to claim that firms have an incentive to underprice the IPO of their firm's stock to ensure its wide distribution, thus reducing the likelihood of being monitored or removed by new shareholders, and in particular, by large institutional shareholders. Managers or directors have some private benefits, which may not be consistent with the benefits of shareholders or non-directors. As such, there is a conflict of interest or an agency problem between managing and nonmanaging shareholders. Within this agency-cost framework, Brennan and Franks (1997) argue that managers have an incentive for more diffused ownership through the underpricing of shares to avoid being monitored by a large outside shareholder. In effect, managers use underpricing as a means of control.

Based on the information cascades theory, Welch (1992) argues that issuing companies underprice to attract the first few potential investors to buy, and thereby induce a cascade in which all subsequent investors want to buy irrespective of their private information. In such a situation, investors look into whether the issues are strongly demanded or not before deciding to subscribe. Essentially, subsequent investors, ignoring their own private information, would examine the reactions of earlier investors. Hence, it can be argued that companies underprice to set up a cascade effect to attract those subsequent investors.

Finally, investor sentiment theories argue that optimism from investors will lead to the underwriter setting a higher offer price beyond the fundamental price as it is expected

${ }^{24}$ Ljungqvist (1997) and Keloharju (1993). 
that these investors will buy shares in the aftermarket. However, as the price reverts to its fundamental value in the long run, underperformance is observed. To this effect, Aggarwal and Rivoli (1991) document fads or overvaluations in the IPO market using a sample of 1598 offerings for the period 1977-87. Essentially, they find that prices fall in the year following their offerings. Also, Ritter and Welch (2002) report over-enthusiasm among retail investors which may account for the initial trading price rise as well as for low aftermarket returns on the first few years. Additionally, Derrien (2005) documents a positive link between investor sentiment, proxied by large individual investors' demands, and high initial returns.

\section{An Overview of the Stock Exchange of Mauritius (SEM)}

The Stock Exchange Act was enacted in 1988 to provide for the setting up of a Stock Exchange Commission (SEC), a regulatory body, as well as the Stock Exchange of Mauritius Ltd (SEM), a private company, established to operate and maintain the stock exchange. On 5 July 1989, the first trading session took place with five companies listed on the official market. Also, the SEMDEX, ${ }^{25}$ a market-weighted index, was created to reflect the collective price movements of all companies listed on the official market. In 1990, the over the counter (OTC) market, now known as the Development and Enterprise market (DEM), and the debt market, were launched. Furthermore, the official market of the Stock Exchange has categorised the companies listed into 7 sectors - namely, Banks and Insurance, Industry, Investments, Sugar, Commerce, Leisure \& Hotels, and Transport.

Other major developments in the Mauritian equity market include the setting up of a centralised clearing and settlement system in 1997, the setting up of a new regulatory body known as the Financial Services Commission in 2001, and the implementation of the Stock Exchange of Mauritius Automated Trading System (SEMATS), replacing the open-outcry single auction method and the replacement of the old Stock Exchange Act 1988 by the Securities Act 2005, amongst others.

\footnotetext{
${ }^{25}$ The SEMDEX is an all shares index. It reflects capitalisation based on each listed stock which is weighted according to its shares in the overall market. The current value of the SEMDEX is expressed in relation to a base period, 5 July 1989, with a value of 100.
} 


\section{Research Methodology \\ 4.1 Sample and Data Collection Methods}

The sample used in this study consists of all Mauritian firms which went public on the official market of the Stock Exchange of Mauritius for the period 1989 until 2010. Given the limited number of firms, we have included those which delisted during the sample period. ${ }^{26}$ However, Gasbarro et al. (2003) argue that the sample size is also relatively small in other emerging market IPO studies. For instance, Hameed and Lim (1998) and Omran (2005) both use a sample size of 53 firms to assess IPO anomalies on the Singaporean and Egyptian markets respectively. There are also other studies such as Lyn and Zychowicz (2002), and Dawson (1987), who consider 33 and 21 new issues on the Hungarian and Malaysian markets respectively.

Four types of data are required for the purpose of the study: prospectus data, annual reports, publications by the stock exchange and share price data. The prospectus is used to collect data prior to listing. These include the offer price, issue details, dates and amounts, the sponsoring stockbroker, the auditor, and financial information from balance sheets and income statements. However, for some firms there is no prospectus and in such cases the annual reports before the year of listing are used to collect ex ante information. Also, information on the issue details of such firms is manually collected from the Registrar of Companies, which keeps files for all private and public companies in Mauritius. Furthermore, the SEM Handbook, which provides a five year summary of income statements and balance sheets for all listed companies, is also consulted. Moreover, the SEM Factbook, an annual publication issued by the SEM to disseminate information to investors, is used to collect information on the main market indicators as well as information pertaining to rights issues and bonus issues by listed companies. In addition, daily price histories were collected for each sample firm through the period 1989 to 2010. In particular, daily share price data for all sample firms from the listing date up to three years subsequent to listing are obtained from the SEM's own quotes as well as from different stock broking companies. Finally, the SEMDEX values for the period 1989 to 2010 are collected to proxy the market returns.

\footnotetext{
${ }^{26}$ There are seven firms which have delisted during the period 1989-2010. The SEM codes for these firms are CIT, COURTS, DELPHIS, GBH, LIT, MDA(O) and MOUNT.
} 


\subsection{Underpricing Measurement}

There are a number of methods available to compute a measure for underpricing. For comparative purposes, the basic methodology followed in this study is similar to those used in earlier studies. ${ }^{27}$ A simple, raw measure of underpricing or first day initial return $\left(R_{i 1}\right)$ for each firm is calculated from the date of issue as follows:

$$
R_{i 1}=\left(P_{i 1} / P_{i 0}\right)-1
$$

where $P_{i 0}$ is the offer price of the firm $i, P_{i 1}$ is the first day closing prices of the shares in firm $i$, and $R_{i 1}$ is the total first day return on the stock.

If markets are highly volatile such that there is a major change in the price of most stocks during the IPO period, then initial returns should be market adjusted. To compute the first day market adjusted return, the return of the market index is initially calculated as

$$
R_{m 1}=\left(P_{m 1} / P_{m 0}\right)-1
$$

where $R_{m 1}$ is the one-day return for the market index (SEMDEX) corresponding to the offering by firm $i, P_{m 1}$ is the closing value of the market index on the issue date corresponding to the offering by firm $i$ and $P_{m 0}$ is the value of the market index corresponding to the offering price of the firm $i$.

The market adjusted return abnormal return for each IPO on the first trading day is therefore computed as:

$$
M A A R_{i 1}=100 \times\left\{\left[\left(1+R_{i 1}\right) /\left(1+R_{m 1}\right)\right]-1\right\}
$$

where $M A A R_{i 1}$ is the one day excess return corresponding to the issue by firm $i, R_{i 1}$ is the one day return for firm $i$, and $R_{m 1}$ is the one day return for the market index corresponding to the offering by the firm $i$.

\footnotetext{
${ }^{27}$ See the studies from McDonald and Fisher (1972), Aggarwal, Leal and Hernadez (1993), AffleckGraves, Hegde and Miller (1996), Dongwei and Fleisher (1999), Mok and Hui (1998), and Paudyal, Saadouni and Briston (1998).
} 
However, the measure in equation (3) rests upon the assumption that the systematic risk of the IPOs under consideration is the same as that of the index. Indeed, it is highly unlikely that the betas of the IPOs average to unity, as a number of studies (e.g., Ibbotson (1975), and Affleck et al. (1996)) have shown that the average betas of the newly listed firms are systematically higher than one. As such, the $M A A R_{i 1}$ may be upwardly biased in the sense that a higher initial performance of the IPO relative to the market could be observed. $^{28}$

The average first day initial return $\left(\bar{R}_{i 1}\right)$ and the average first day market adjusted return $(\overline{M A A R})$ are calculated as

$$
\begin{aligned}
& \bar{R}_{i 1}=1 / N \sum_{i=1}^{N} R_{i 1} \\
& \overline{M A A R}=1 / N \sum_{i=1}^{N} M A A R_{i 1}
\end{aligned}
$$

According to Kooli and Suret (2002), first day returns are generally appropriate where there is no time gap between the application closing date and the first day of trading. As such, some studies ${ }^{29}$ have used first week or first month returns to assess the degree of underpricing. The time gap for the Mauritian market is relatively long compared to developed markets and so it may be useful to consider first week or first month returns, although they are rarely used as measures of underpricing in the literature. To calculate the underpricing level based on first week or first month returns, the same methodologies as defined above are used.

\footnotetext{
${ }^{28}$ To cater for this anomaly, it would be most appropriate to construct a portfolio having the same risk as the IPO. As such, some studies (e.g., Ritter, 1991; Loughran and Ritter, 1995) consider initial returns which are adjusted by taking into account the returns of matching firms. However, matching adjustment methods are rarely used, probably because it is time consuming and difficult to find matching firms unless there is a very large sample available to the researcher. Indeed, the sample size is significantly limited for the Mauritian market. Therefore, the $M A A R_{i 1}$ will be used as an adjustment to the raw underpricing measure. This is also consistent with the existing literature whereby most studies prefer to use the market adjusted returns.

${ }^{29}$ Reilly and Hatfield (1969), McDonald \& Fisher (1972), and Beatty and Ritter (1986).
} 


\subsection{Explaining the Short-run Underpricing of IPOs: The Regression Model}

To explain the factors accounting for the short run underpricing of IPOs, two measures are used as the dependent variable: the simple raw initial returns and the market-adjusted initial returns of IPOs that went public from 1989 until 2005. The explanatory variables, based on the literature discussed above, include proxies for the ex ante uncertainty of the firm, signalling mechanisms and underwriter reputation. The multiple regressions employed are

$$
\begin{aligned}
& R_{i t}=\alpha+\beta_{1} \text { ROA }_{i}+\beta_{2} \text { SIZE }_{i}+\beta_{3} A G E_{i}+\beta_{4} \text { FINLEV }_{i}+\beta_{5} \text { RISK }_{i}+\beta_{6} \text { ZSCORE }_{i}+ \\
& \beta_{7} \text { EPS }_{i}+\beta_{8} \text { SEO }_{i}+\beta_{9} \text { BROKREP }_{i}+\beta_{10} \text { AUDITREP }_{i}+u_{i} \\
& \text { MAAR }_{i t}=\alpha+\beta_{1} \text { ROA }_{i}+\beta_{2} \text { SIZE }_{i}+\beta_{3} A G E_{i}+\beta_{4} \text { FINLEV }_{i}+\beta_{5} \text { RISK }_{i}+ \\
& \beta_{6} \text { ZSCORE }_{i}+\beta_{7} \text { EPS }_{i}+\beta_{8} \text { SEO }_{i}+\beta_{9} \text { BROKREP }_{i}+\beta_{10} \text { AUDITREP }_{i}+u_{i}
\end{aligned}
$$

where $R_{i 1}$ and $M A A R_{i 1}$ are the first day raw and excess return (as defined above) corresponding to the issue by firm $i$ respectively. A description of the independent variables used as well as the expected relationships is summarized in Table 1.

\section{[INSERT TABLE 1 AROUND HERE]}

\subsection{The Financial Strength of IPOs and the Altman Z-score Model}

According to Gasbarro et al. (2003), the financial strength of IPOs can be proxied using Altman's (1968) Z-score model, which was initially used to predict the survival rates of public companies. To the authors' knowledge, there has not been any comprehensive application of the Z-score model to estimate the ex ante financial strength of IPOs. Altman (2000) argues that, “... the most frequent inquiry that I have received from those interested in using the Z-Score model is, 'What should we do to apply the model to firms in the private sector?"'. To this effect, Altman (2000) undertakes a re-estimation of the original Z-score model. ${ }^{30}$ In this model, the book value of equity is replaced by the market value of equity. As such, based on Altman's bankruptcy model, the financial strength of IPOs is measured as

$$
Z_{i}=0.717 X_{1 i}+0.847 X_{2 i}+3.107 X_{3 i}+0.420 X_{4 i}+0.998 X_{5 i}
$$

\footnotetext{
${ }^{30}$ Altman (2000) suggests a complete re-estimation of the model “....rather than simply inserting a proxy variable into an existing model to calculate Z-scores".
} 
where $Z_{i}$ proxies the financial strength of firm $i$ and $X_{1 i}, X_{2 i}, X_{3 \mathrm{i}}, X_{4 i}$ and $X_{5 i}$ measure the liquidity, profitability, productivity of assets, leverage and income generating ability of the firm respectively. In particular, firms will be partitioned into two categories, high and low financial health groups, based on the Z-scores. Following Altman (2000), those firms having of a score less than 1.23 will be considered to be in the low financial health group.

\section{Analysis and Findings}

\subsection{Aggregate Underpricing}

The section examines whether an investor who bought all IPOs from when the SEM was set up until 2005 at the offer price and sold them on the first day, first week or first month of their listing, earned a significant abnormal return. In particular, a fixed amount of money is assumed to be invested in every IPO. As such, the null hypothesis entails that the average raw or abnormal returns are not significantly different from zero. Table 2 reports the average first day, first week and first months returns for the 44 IPOs during the period 1989 to 2005 . It is observed that the average raw (unadjusted) initial return is $14.29 \%$, while the average market index-adjusted initial return is $13.14 \%$. In addition, an investor can earn at least an additional average return of $3 \%$ if the IPOs are held either until their first week or first month of listing. The average returns are the highest if the investor buys and holds every IPO until the end of their first month. However, one must also note that risks are the highest for first month returns relative to the first day or first week returns.

\section{[INSERT TABLE 2 AROUND HERE]}

As the distribution of the first day, first week and first month returns are not symmetric, ${ }^{31}$ a bootstrapped skewness-adjusted $t$-statistic ${ }^{32}$ is used to test the null hypothesis of no significant average return. The results show that in all cases, the returns are statistically significant at the $1 \%$ level, indicating that Mauritian IPOs are on average underpriced. This evidence is consistent with that for almost all IPO markets in different countries. In particular, it is found that the level of underpricing on the SEM is consistent with findings

\footnotetext{
${ }^{31}$ The mean being greater than the median in all cases, implying that the returns are positively skewed.

32 The bootstrapped skewness-adjusted $t$-statistic is developed by Lyon, Barber, and Tsai (1999). Rajesh Tharyan and Scott Merryman from Centre for Finance and Investment, University of Exeter, UK provided the programme code in Stata to compute the skewness adjusted $t$-statistic.
} 
for countries such as the U.S, U.K, Australia, and Germany, where the degree of underpricing is found to be in the range $10-20 \%{ }^{33}$ However, the extent of average underpricing is much smaller when compared to some major South-East Asian markets such as Malaysia, Korea, Thailand, Singapore or Japan, ${ }^{34}$ where an average underpricing level of least $30 \%$ is reported. Compared to the African markets, Mauritian IPOs generally experience a higher degree of average underpricing, as Alli et al. (2010) and Omran (2002) report an average first day return of $7.08 \%$ and $8.4 \%$ on the South-African and Egyptian markets respectively.

From Table 2, one can note that the average first day return is around $14 \%$. Also, most of the price reactions are likely to occur during the first days of trading given that the initial first day market adjusted return is approximately 13\%, while the first week and first month underpricings do not exceed 17\%. This is in line with Aggarwal et al. (1993), where an underpricing level of $78.5 \%$ is observed for the Brazilian market on the first day of trading while monthly underpricing (including the first day) is $90.2 \%$.

Although there may be positive average initial returns on the Mauritian IPO market, there is a wide variation across the individual issues. None of these IPOs suffer from negative initial returns and one in four IPOs closes on the first day at the offer price. The probability of an IPO closing at the offer price is relatively higher in the Mauritian market considering that Ritter (1998) reports that one in six IPOs terminates at the offer price on the US market. In addition, a limited number of companies (only eight out of 44) on the Mauritian market have exceeded a return of $20 \%$ on their first day. In fact, there are only two IPOs which have managed to earn a return of greater than $50 \%$. Overall, eight out of ten IPOs on the Mauritian market have a return between 0 and $20 \%$ on their first day.

\footnotetext{
${ }^{33}$ Ritter and Welch (2002) for the US markets, Levis (1993) for the UK market, and Ljungqvist (1993) for the German Market.

${ }^{34}$ Isa \& Yong (2003) for the Malaysian market, Kim, Krinsky and Lee (1995) for the Korean Market, Dawson (1987) for the Singaporean market, and Hibara and Mathew (2004) for the Japanese market.
} 


\subsection{The Size Effect and Average Underpricing}

To analyze the effect of the firm's size on the initial returns of the companies on the SEM, the sample is divided according to the median market capitalisation of the firm. In line with the ex ante uncertainty hypothesis where small firms are subject to more ex ante uncertainty, Table 3 shows that average unadjusted and market adjusted initial returns are higher for smaller companies and lower for larger companies. However, the Wilcoxon test shows that the difference in the underpricing between large and small firms is statistically insignificant. In effect, when the sample is segregated into quartiles, there are no discernible patterns between the market capitalization and the level of underpricing. Hence, on the basis of those results, the size of the company going public on the SEM is not related to the return obtained by the investor on the IPO. This result is inconsistent with the findings of Ritter (1991), Barry et al. (1991) and Clarkson and Merkley (1994) amongst others. However, this result may be supported by the fact that the large firms in this sample are not really large by international standards.

\section{[INSERT TABLE 3 AROUND HERE]}

\subsection{Motives for Going Public and Average Underpricing}

To reflect the issuers' motives for going public, the sample is divided into two categories by offer type. In the Mauritian context, as per the listing rules of the SEM, it is only when firms go public through an "offer for subscription" that new shares are issued and sold to the public, whereas other methods of listing such as "introduction", "offer for sale" or "placings" do not involve any issue of new securities. As such, in Table 4, the NEW category includes 14 firms issuing new shares only while 30 firms in the OLD category offer old shares. In particular, firms normally issue new shares as a means to fund capital projects. However, since the inception of the SEM, a relatively low proportion of firms have gone public with the primary motive of raising capital. In the Mauritian context, this can be explained by the fact that firms were mainly attracted to the tax reductions from $35 \%$ to $25 \%$ which were provided to listed companies by the government in the early 1990s as an incentive to boost the local stock exchange. Also, firms were keen to list as the stock exchange provided opportunities for existing shareholders to increase the marketability of their shares. 
As documented by Kim et al. (1993), if firms need funds for projects, there will be more pressure on the IPO proceeds, leading to a lesser degree of underpricing. As expected, the initial performance of the NEW group, 15.05\%, is higher than the OLD category, $12.24 \%$. However, a test for the difference of performance between the two groups is statistically insignificant. As such, the results confirm that, on the SEM, the degree of underpricing does not depend on the motives of the firm going public.

\section{[INSERT TABLE 4 AROUND HERE]}

\subsection{Stock Broker Reputation, Auditor Reputation and Average Underpricing} According to Carter and Manaster (1990), high quality underwriters are, on average, associated with IPOs which have a lower degree of underpricing. In order to test this hypothesis, two proxies are used, namely the stockbroker's reputation and the auditor's reputation. In the finance literature, prior studies ${ }^{35}$ have traditionally focused on firm size as a proxy for measuring quality. ${ }^{36}$ DeAngelo (1981) argues that the rationale for this standard is that larger audit firms supply higher quality since they stand to lose more than smaller firms in terms of reputation. In this respect, stockbroker reputation is measured taking into account the number of IPOs which have been sponsored by respective stockbrokers while the measure of auditor reputation takes into account the proportion of the total number of IPOs which have been audited by that firm. The sample is initially partitioned into two groups on the basis of stockbroker and auditor quality (HIGH and LOW). In particular, firms are grouped in the high category if they are sponsored by either MCB or CIM Stockbroker Ltd since these two stockbroking companies capture more than $55 \%$ of the IPO market. Similarly, firms which are audited by DCDM are grouped in the high category as DCDM audits more than 55\% of listed firms on the official market of the SEM. From Table 5, 29 and 25 out of 44 offerings are brought to the market by high quality stockbrokers and auditors respectively.

\section{[INSERT TABLE 5 AROUND HERE]}

With regards to stockbroker reputation, Table 5 shows that the average values for the initial unadjusted price run-up are higher, as expected, if issues are sponsored by low

\footnotetext{
${ }^{35}$ Becker et al. (1998), DeAngelo (1981), Francis and Wilson (1988) and Krishnan and Schauer (2000).

${ }^{36}$ However, Beatty (1989) argues that the classification of a firm's size may be insufficient for capturing variations in audit quality.
} 
quality stockbroking companies. However, when returns are market-adjusted, this result is insignificant. Moreover, a test for the difference of performance between the HIGH and LOW stockbroker groups is statistically insignificant. Based on these results, the degree of underpricing is not related to the reputation of stockbrokers on the SEM. As far as the auditor's reputation is concerned, Table 5 indicates that the average initial price run-ups are positively related to the quality of the auditor. The mean of the initial market adjusted returns is $15.09 \%$ for HIGH quality auditors and $10.57 \%$ for LOW quality auditors. Also, the average unadjusted and adjusted initial returns of IPOs in the HIGH audit category are higher than the underpricing level of IPOs in the LOW audit category. The Wilcoxon test shows that the difference in the underpricing is statistically significant at the $5 \%$ level. In effect, one would expect that a higher auditor's reputation will be associated with lower ex ante uncertainty so that such firms should exhibit a lower degree of underpricing. This result is confirms the significance of the signalling effect of auditor's quality in the Mauritian market. In particular, the value of the IPO seems to be an increasing function of the auditor's quality such that the appointment of higher quality auditors contributes to higher underpricing.

Measuring stockbroker and auditor reputation is somewhat tricky in Mauritius since the market is completely dominated by two firms that capture over half of the market share. Those big firms are mainly the local pioneering financial services providers and have build a solid reputation over the years such that there are less uncertainty surrounding their future. In this respect, the context of Mauritian market quite unique given the smallness of the market and the monopolistic nature of its financial services industry. In effect, to test the validity of the reputation measure, the auditing and stock broking firms were also ranked in terms of their turnover and age. The results are consistent with our earlier predictions in that those firms with the highest turnover and age also fall within the highest reputation category. As such, we consider the number of IPOs sponsored or audited as a reasonable proxy for the stock brokering or auditing firms' reputation. This measure has also been adopted by a number of existing studies ${ }^{37}$ in the literature.

\footnotetext{
${ }^{37}$ Francis and Wilson (1988), Becker et al. (1998), Jelic et al. (2001), Krishnan and Schauer (2000) and Bulut et al. (2009)
} 


\subsection{Financial Strength and Average Underpricing}

Table 6 presents information on the relationship between the financial strength and the level of underpricing. In particular, financial strength is proxied by the Altman (2000) Zscore. The sample is partitioned into HIGH and LOW financial strength groups. Firms having a score less than 1.23 are placed in the LOW financial health group. From Table 6 , the results show that there are slightly more firms in the HIGH financial group. Also, the average underpricing is higher for firms in the HIGH strength group than firms with lower financial strength. In addition, the Wilcoxon test shows that the difference in underpricing is statistically significant at the 5\% level. The results are consistent with the ex ante uncertainty hypothesis ${ }^{38}$ but inconsistent with the predictions of signalling theories as supported by Allen and Faulhaber (1989), Welch (1989) and Grinblatt and Hwang (1989).

\section{[INSERT TABLE 6 AROUND HERE]}

While the Z-score is probably the most reliable and well respected composite measure of financial strength, in order to investigate its robustness, we also employ another proxy based on aftermarket information. In particular, based on the a number of previous studies, ${ }^{39}$ the return to risk ratio is used and is calculated as the average monthly return during the first three years of listing divided by the standard deviation of post IPO returns. The results show that higher financial strength is associated with lower average underpricing, consistent with when the Altman Z-scores are used as proxies for financial strength. In addition, through further analysis, companies with lower Z-scores seem on average to have lower return to risk ratios and vice-versa. To this effect, the Z-score model based on financial statement information seems to be consistent with the riskreturn partition which is based on market returns.

\subsection{Short-Run Aftermarket Performance and Average Underpricing}

Table 7 presents the initial and short-term returns for the sample of IPOs listed on the SEM. On average, the investor earns a return of $13.14 \%$ if the stock is bought at the offer

\footnotetext{
${ }^{38}$ Ritter (1984), Beatty and Ritter (1986), Ritter (1991), Garfinkel (1993), Ljungqvist and Wilhelm (2003), and Ljungqvist (2006), amongst others.

${ }^{39}$ Ritter (1991), Carter and Manaster (1990).
} 
price and sold thereafter on the secondary market on the first listing date of the IPO. However, for those buying IPOs in the aftermarket, the opportunity to earn a similar average return is not available as the highest average abnormal returns after the first day of trading do not exceed $3.67 \%$. In fact, after the fourth day of trading, the average initial abnormal return turns negative. As such, for the overall sample, the observed initial abnormal day-to-day returns are positive but dissipate beyond the first four days of trading. This finding is consistent with results for the South African market where Alli et al. (2010) claim that "the opportunity for an abnormal return is only available to those investors able to buy the offering at the offer price and not to those buying these stocks in the aftermarket."

\section{[INSERT TABLE 7 AROUND HERE]}

Considering the initial returns by industry segment, IPOs in the Commerce sector seem to benefit from positive average abnormal returns during six out of seven days after the listing event. However, the initial average market adjusted return is positive and highest on the listing date, but fall after the first few days of trading. This finding also seems consistent when controlling for market size, offer size, offer type, stockbroker reputation, auditor reputation and financial strength.

\subsection{Underpricing Regression Analysis and Empirical Results}

In this section, several cross-sectional regressions are estimated using ordinary least squares (OLS) to assess the factors affecting short-run underpricing. In particular, the dependent variable is level of underpricing based on two proxies, namely the initial raw returns and the market-adjusted initial returns. ${ }^{40}$ The explanatory variables are proxies based on the ex ante uncertainty hypothesis, the signalling hypothesis and the underwriter reputation hypothesis. The regression results to explain the short-run initial raw returns are presented in Table 8. There is no serious multicollinearity among any of the explanatory variables and heteroscedasticity in the residuals is accounted for by adjusting the standard errors using the procedure of White (1980).

\footnotetext{
${ }^{40}$ However, only the results from the regressions using the market-adjusted returns are presented to avoid repetition. The findings are qualitatively identical.
} 
Despite that we include all IPOs on the Mauritian market since its inception, the sample size is necessarily small. Therefore, in order to ensure that our inferences are as robust as possible and to account for the impact that non-normality of the residuals may have at such sample sizes, we implement a bootstrap procedure to construct p-values for each parameter in a fashion that does not require the normality assumption. Specifically, the bootstrap approach that we adopt is conducted as follows. For all models estimated, we collect the residuals and produce 10,000 bootstrapped samples each of the same size as the original sample (44 observations). For each of these replications, we reconstruct the dependent variable by adding the resampled residuals to the original regression fitted values to obtain a set of bootstrapped observations on the dependent variable. We then rerun the regression for each of these 10,000 replications and collect the t-ratios for each parameter estimated. We can then compare the actual t-ratios with these simulated distributions to obtain a bootstrapped $\mathrm{p}$-value for each parameter that can be examined alongside the conventionally calculated p-values. This approach is adopted for all of the regressions that we conduct in this study.

The first regression model in Table 8 tests for the relevance of the ex ante hypothesis to explain the short-run underpricing of IPOs. Model 1 shows that, among several proxies for the ex ante uncertainty of IPOs, the aftermarket risk level and the ex ante financial strength are the only variables which are statistically significant at the 5\% and $10 \%$ levels respectively. In effect, the results confirm a positive and marginally significant relationship between underpricing and the aftermarket risk level. In addition, the results show that firms will on average underprice less if they are financially stronger. Neither is significant according to the bootstrapped p-values for the "large" models including all ten explanatory variances, although they are significant in model 5. These results are consistent with the predictions of previous studies, ${ }^{41}$ and confirm that the greater is the ex ante uncertainty of the issue, the greater is the expected underpricing. However, other variables such as the return on assets, age, size of the offering and financial leverage, acting as proxies for the ex ante uncertainty of the issue, are statistically insignificant in the Mauritian market. In this respect, it must be highlighted that none of the accounting

\footnotetext{
${ }^{41}$ Beatty and Ritter (1986), Aussenegg (2003), and Lowry et al. (2010), amongst others.
} 
variables tested can be considered good proxies for ex ante uncertainty. However, the Altman Z-score, taking into account several aspects of the financial statements, seems to reflect investors' perceptions regarding the ex ante uncertainty of the firm.

\section{[INSERT TABLE 8 AROUND HERE]}

On the other hand, model 2 shows limited support for signalling theories on the SEM as firms having higher profitability ratios and exercising seasoned offerings do not on average experience higher underpricing. ${ }^{42}$ In addition, there is a significant (at the $10 \%$ level according to the standard and bootstrapped p-values) and negative relationship between the ex ante financial strength and the level of underpricing suggesting that the ex ante uncertainty effect of this variable dominates the signalling effect. In particular, the high Z-score is viewed by the market as a proxy surrounding the uncertainty of the issue rather than as a proxy for the quality of the issue such that the negative relationship is consistent with the ex ante hypothesis.

With regard to model 3, two proxies - stockbroker reputation and auditors' reputation are used to test the underwriter reputation hypothesis. The results suggest that there is no significant relation between stockbroker reputation and the level of underpricing. However, there is a positive and significant relationship between the auditor's reputation and the initial raw returns for both the conventional and bootstrapped p-values. In particular, IPOs which are audited by a well known and prestigious auditing company will on average exhibit a higher level of underpricing. This result, though significant, is inconsistent with the expected predictions of the underwriter reputation hypothesis as one expects a negative rather than a positive relationship to prevail. ${ }^{43}$ Hence the signalling role of audit quality seems to dominate the Mauritian market. In effect, one may claim that the better the auditing firm, the better the perceived quality of the company such that there is a higher aftermarket demand for the IPO, leading to a higher aftermarket price. This seems consistent with the signalling theories of Allen and Faulhaber (1989), Grinblatt and Hwang (1989) and Welch (1989), where firms which are more likely to be underpriced.

\footnotetext{
42 The results are consistent with the findings of James (1992), and Michaely and Shaw (1994), who find no support for the signalling hypothesis.

${ }^{43}$ Balvers et. al. (1988), Carter and Manaster (1990), and Kim et al. (1993).
} 
Model 4 considers all explanatory variables from all hypotheses. As one can observe, the risk level, the financial strength and the auditor's reputation are the only variables which are statistically significant in explaining the initial raw returns, although neither are significant according to the bootstrapped p-values in this particular specification as this model is probably overparameterised given the modest sample size. This result is consistent with model 5, which is obtained after successive variable deletion tests, removing the insignificant variables, but now the Z-score variable is highly significant and the risk variable is almost significant even with the bootstrap-constructed p-values. Overall, firms with a higher aftermarket risk level, lower financial strength and higher auditing firm reputation will on average exhibit a higher degree of underpricing.

\subsection{Multiple Regressions to Explain the Short Run Performance of IPOs}

According to Mok and Hui (1998), the level of underpricing is likely to be greater following longer gaps between the application closing date and the first day trading. As such, some studies ${ }^{44}$ prefer to use the first week's or first month's returns as measures of underpricing. Therefore, the first day underpricing calculations are now extended to the first week and the first month returns. In particular, the dependent variable measures the short run performance of IPOs taking into account the first week raw and market adjusted returns as well the first month raw and market adjusted returns. The results from Table 9 are consistent with the above findings in that the risk level of the issue and the auditor's reputation are statistically significant when the first week and first month returns (both adjusted and un-adjusted) are used. When we consider the bootstrap p-values, this result only applies when the reduced form model including only three or four explanatory variables is used due to the insufficient number of degrees of freedom from the full specification. However, the financial strength variable is only significant when underpricing calculations are extended to first week returns. In general, among the eight regression models used in Table 9, there seems to be strong support for firms with a higher aftermarket risk level and higher auditing firm reputation to on average exhibit a higher degree of underpricing.

\section{[INSERT TABLE 9 AROUND HERE]}

${ }^{44}$ Aggarwal, Leal and Hernandez (1993) and Pauydal, Saadouni and Briston (1998) amongst others. 


\section{Conclusions}

Taking into account all firms which have gone public on the official market of the Stock Exchange of Mauritius for the period 1989 until 2010, this study examines the evidence on the short-run underpricing of IPOs. In particular, an average underpricing level within the range 10 to $20 \%$ is found based on first day, first week and first month returns. When considering the short-run aftermarket performance and average underpricing, the investor earns an average initial return of $13.14 \%$. However, after the fourth day of trading, the average initial abnormal return turns negative. Using a regression approach, the degree of underpricing is explained by the ex ante uncertainty hypothesis and the underwriter reputation hypothesis. However, there is limited support for the signalling hypothesis. In particular, the results show that the aftermarket risk level and auditor's reputation both have a significant positive impact on the initial returns while the ex ante financial strength (based on the Altman Z-score) has a significant negative effect on short-run underpricing. Firms with a higher aftermarket risk level, weaker financial strength and stronger auditing firm reputation will on average exhibit a higher degree of underpricing. However, the results show that there is no statistically significant relationship with other explanatory factors such as return on assets, offer size, age, earnings per share, seasoned equity offerings, stockbroker reputation and the level of underpricing.

The results obtained from this study show that new issues on the SEM are subject to underpricing, consistent with developed and other emerging markets. In this respect, prospective investors should pursue the strategy of buying the new issues at the offer and selling them immediately on the first day of trading. However, the study also reveals that investors should not hold new issues very long as the highest component of the initial returns is found on the first day of trading and that the average initial returns turn negative on the fourth day of trading.

\section{Acknowledgements}

We thank the Editor, Brian Lucey, and the anonymous referee for useful comments that helped to improve the paper. 


\section{References}

Adjasi, C.K.D., Osei, K.A., and Fiawoyife, E.U., 2011. Explaining underpricing of IPOs in frontier markets: Evidence from the Nigeria Stock Exchange. Research in International Business and Finance. 25(3), 255-265.

Affleck-Graves, J., Hedge, S. and Miller, R.E., 1996. Conditional price trends in the aftermarket for initial public offerings. Financial Management. 25, 25-40.

Al-Hassan, A., Delgado, F., and Omran, M., 2010. The under-pricing of IPOs in the Gulf cooperation council countries. Research in International Business and Finance. 24(3), 344-360.

Aggarwal, R., and Rivoli, P., 1991. Evaluating the costs of raising capital through an initial public offering. Journal of Business Venturing, 6(5), 351-361.

Aggarwal, R., Leal, R., and Hernandez, L., 1993. The aftermarket performance of initial public offerings in Latin America. Financial Management, 22, 42-53.

Allen, F., and Faulhaber G.R., 1989, Signaling by Underpricing in the IPO Market, Journal of Financial Economics, 23, 303-323.

Alli, K., Subrahmanyam, V., and Gleason,K.C., 2010. Short and long run performance of IPOs in Post-apartheid South Africa. Journal of African Business 11, 1-25.

Altman, E., I., 1968. Financial Ratios, Discriminant Analysis and the Prediction of Corporate Bankruptcy. Journal of Finance, 23(4), 589-609.

Altman, E., I., 2000. Predicting Financial Distress Of Companies: Revisiting the Z-Score and Zeta Models: Altman's Stern School of Business, New York University.

Aussenegg, W., 2003. Privatization Versus Private Sector: Initial Public Offerings in Poland. Multinational Finance Journal, 4 (1-2), 69-99.

Banerjee, S., Dai, L., and Shrestha, K., 2011. Cross-Country IPOs: What Explain Differences in Underpricing? Journal of Corporate Finance 17(5), 1289-1305.

Baron, D.P., 1982. A Model of the Demand for Investment Banking Advising and Distribution Services for New Issues. Journal of Finance, 37, 955-976.

Barry, C. B., Muscarella, C. J. Peavy, J. and Vetsuypens M. R., 1991. The role of venture capital in the creation of public companies: evidence from the going-public process. Journal of Financial Economics 27, 447-472.

Beatty, R. P. 1989. Auditor Reputation and the Pricing of Initial Public Offerings. The Accounting Review 64: 693-709. 
Beatty, R. and Ritter, J.R., 1986. Investment Banking, Reputation, and the Underpricing of Initial Public Offerings. Journal of Financial Economics, 15, 213-232.

Beatty, R. and Welch, I., 1996. Issuer expenses and legal liability in initial public offerings. Journal of Law and Economics, 39, 545-602.

Becker, C. L., Defond, M. L., Jiambalvo, J., and Subramanyam K. R., 1998. The Effect of Audit Quality on Earnings Management. Contemporary Accounting Research. 15, 124.

Benveniste, L.M. and Spindt, P.A., 1989. How Investment Bankers Determine the Offer Price and Allocation of New Issues. Journal of Financial Economics, 24, 343-361.

Benveniste, L.M., Ljungqvist, A., Wilhelm, W.J. and Yu, X., 2003. Evidence of information spillovers in the production of investment banking services. Journal of Finance. 58, 577-608.

Bommel , J.V., Dahya, J. and Shi,Z. 2006. An Empirical Inquiry into the Speed of Information Acquisition: A Study of IPOs Working paper.

Booth, J.R. and Smith, R.L., 1986. Capital raising, underwriting and certification process. Journal of Financial Economics, 15, 261-281.

Boulton, T. J., Smart, S. B., and Zutter, C. J., 2007. IPO underpricing and international corporate governance. Working paper, Miami University.

Brau, James C. and Rodriguez, J., 2009. An empirical analysis of Mexican and US closed-end mutual fund IPOs. Research in International Business and Finance. 23(1), 117.

Brennan, M.J., and Franks, J., 1997. Underpricing, Ownership and Control in Initial Public Offerings of Equity Securities in the U.K. Journal of Financial Economics. 45, 391-413.

Bundoo S., K., 2007. An Analysis of IPOs Underpricing in Mauritius. African Journal of Accounting, Economics, Finance and Banking Research. 1(1), 1-12.

Carter, R. B., Dark, F. H., and Singh, A. K., 1998, Underwriter reputation, initial returns, and the long-run performance of IPO stocks, Journal of Finance. 53, 285-311.

Carter, R.B., and Manaster, S., 1990. Initial Public Offerings and Underwriter Reputation. Journal of Finance. 45, 1045-1067.

Chahine, S. and Saade, S. ,2011. Shareholders' Rights and the Effect of the Origin of Venture Capital Firms on the Underpricing of US IPOs. Corporate Governance: An International Review. 19, 601-621. 
Chen Z., Choi J. J., and Jiang C., 2007. Corruption in State Owned Firms: Evidence from China's IPOs, Temple University working paper.

Chorruk, J., A., and Worthington, A., C., 2010. New Evidence on the Pricing and Performance of Initial Public Offerings in Thailand: 1997-2008, Emerging Markets Review. 11, 285-299

Clarkson, P.M. and Merkley, J., 1994. Ex ante uncertainty and the underpricing of initial public offering: Further Canadian evidence. Canadian Journal of Administrative Sciences. 11, 54-67.

Cornelli, F. and Goldreich, D., 2003. Bookbuilding: How Informative is the Order Book? Journal of Finance. 58, 1415-1444.

Corwin, S., and Schultz, P., 2005. The role of underwriting syndicates: pricing, information production and underwriter competition, Journal of Finance. 60, 443-486.

Dawson, S, M., 1987. Secondary stock market performance of initial public offers: Hong Kong, Singapore and Malaysia, Journal of Business Finance \& Accounting. 14, 65-76.

Deangelo, L. E.,1981. Auditor Size and Audit Quality. Journal of Accounting and Economics. 3, 183-99.

Derrien, F., 2005. IPO pricing in "Hot" market conditions: Who leaves money on the table? Journal of Finance. 60, 487-521

Dongwei, S. and Fleisher, B.M., 1999. An Empirical Investigation of Underpricing in Chinese IPOs. Pacific-Basin Finance Journal. 7, 173-202.

Espenlaub, S., and Tonks I., 1998. Post-IPO Directors' Sales and Reissuing Activity: An Empirical Test of IPO Signalling Models. Journal of Business Finance and Accounting, 25, 1037-1080.

Francis, B., and Hasan, I., 2001. The Underpricing of Venture and Non-venture Capital IPOs: an empirical investigation. Journal of Financial Services Research. 19(2), 99-113.

Francis, J. R., and Wilson E. R., 1988. Auditor Changes - a Joint Test of Theories Relating to Agency Costs and Auditor Differentiation. Accounting Review 63(4), 663-82.

Garfinkel, J.A., 1993. IPO underpricing, insider selling and subsequent equity offerings: Is underpricing a signal of quality? Financial Management, 22, 74-83

Gasbarro, D., Bundoo, S. and Zumwalt J.K., 2003. Underpricing and Aftermarket Performance of IPO Firms in Mauritius. Journal of Emerging Market Finance. 2 (3), 315335. 
Ghosh, S., 2004, Underpricing of IPOs: The Indian Experience over the Last Decade, Reserve Bank of India, Working Paper.

Gounopoulos, D., Nounis, C., and Andstylianides, P., 2007. The Short and Long Term Performance of Initial Public Offerings in the Cyprus Stock Exchange, Journal of Financial Decision Making. 4(1), 1-28.

Grinblatt, M. and Hwang, C.Y., 1989. Signalling and the Pricing of New Issues. Journal of Finance, 44, 393-420.

Günther, S. and Rummer, M., 2006. The hot-issue period in Germany: what factors drove IPO underpricing? in Initial Public Offerings: an international perspective, $1^{\text {st }}$ edition by Greg N. Gregoriou. Burlington: Elsevier.

Habib, A.M. and Ljungqvist, A.P., 2001. Underpricing and Entrepreneurial Wealth Losses in IPOs: Theory and Evidence. Review of Financial Studies. 14, 433-458.

Hameed, A. and Lim, G. H., 1998.Underpricing and firm quality in initial public offerings: evidence from Singapore. Journal of Business Finance \& Accounting. 25, 455468.

Hanley, K., 1993, The Underpricing of Initial Public Offerings and the Partial Adjustment Phenomenon. Journal of Financial Economics. 34, 231-250.

Hibara, N. and Mathew, P.G., 2004. Grandstanding and Venture Capital Firms in Newly Established IPO Markets, Journal of Entrepreneurial Finance and Business Ventures. 9 (3), 77-90.

Hoberg, G., 2007. The Underwriter Persistence Phenomenon, Journal of Finance. 62, 1169-1206.

Ibbotson, R.G., 1975. Price Performance of Common Stock New Issues, Journal of Financial Economics. 2, 235-272.

Ibbotson, R.G., Sindelar J. and Ritter J., 1994. The market's problems with the pricing of initial public offerings. Journal of Applied Corporate Finance. 7, 66-74.

Isa. Z., and Yong O., 2003. Initial Performance of New Issues of Shares in Malaysia. Applied Economics 35, 919-930.

Islam, M., Ali, R., and Ahmad, Z. 2010. An Empirical Investigation into the Underpricing of Initial Public Offerings in the Chittagong Stock Exchange, International Journal of Economics and Finance. 2(4), 36-46.

James, C., 1992. Relationship-Specific Assets and the Pricing of Underwriter Services. Journal of Finance. 47, 1865-1885 
Jelic, R. And Briston R., 2003. Privatisation initial public offerings: The Polish experience. European Financial Management. 9, 457-484.

Jelic, R, Saadouni, B., and Briston, R J., 2001. Performance of Malaysian IPOs: Underwriters Reputation and Earnings Forecasts. Pacific-Basin Finance Journal. 9(5), 457-486.

Jenkinson, T. and H. Jones, 2004, Bids and allocations in European IPO bookbuilding. Journal of Finance. 59, 2309-2338.

Jog, V. and Wang, L., 2002. Aftermarket Volatility and Underpricing of Canadian Initial Public Offerings, Canadian Journal of Administrative Sciences / Revue Canadienne des Sciences de l'Administration, 19, 231-248.

Kazantzis, C., and Levis, M., 1995. Price support and initial public offerings: evidence from Athens Stock Exchange. Research in International Business and Finance. 12, 185200.

Keloharju, M., 1993. The Winner's Curse, Legal Liability, and the Long-Run Price Performance of Initial Public Offerings in Finland, Journal of Financial Economics. 34, 251-277.

Kim, J., Krinsky, I., and Lee, J., 1993. Motives for going public and underpricing: New findings from Korea. Journal of Business Finance \& Accounting. 20(2), 195-211.

Kim, J., Krinsky I. and Lee J., 1995. The aftermarket performance of initial public offerings in Korea. Pacific-Basin Finance Journal. 3, 429-448.

Kim, B., Kish, R., and Vasconcellos, G., 2004. Cumulative Returns from the Korean IPO market. Review of Pacific Basin Financial Markets \& Policies. 7(2), 43-75.

Krishnan, J., and Schauer P. C., 2000. The Differentiation of Quality Among Auditors: Evidence From the Not-For-Profit Sector. Auditing: A Journal of Practice and Theory. 19(2): $9-25$.

Leland, H. and Pyle, H., 1977. Informational Asymmetries, Financial Structure, and Financial Intermediation. Journal of Finance. 32 (2), 371-387.

Levis, M., 1990. The Winner's Curse Problem, Interest Costs and the Underpricing of the Initial Public Offerings. Economic Journal. 100, 76-89.

Levis, M., 1993. The long run performance of initial public offerings: The UK experience 1980-88. Financial Management. 22 (1), 28-41.

Liu, Xiaoding, And Jay R. Ritter, 2011. Local Underwriter Oligopolies and IPO Underpricing. Journal of Financial Economics. 102(3), 579-601. 
Ljungqvist, L. 1993. Economic Underdevelopment: The Case of Missing Market for Human Capital. Journal of Development Economics. 40, 219-239.

Ljungqvist, A., 1995. The timing, pricing and long-term performance of initial public offerings. Unpublished dissertation. Nuffield College, Oxford University.

Ljungqvist, A., 1997. Pricing Initial Public Offerings: Further Evidence from Germany. European Economic Review. 41, 1309-1320.

Ljungqvist, A., 2006, IPO Underpricing, in: B.E. Eckbo (ed.). Handbook of Empirical Corporate Finance, North-Holland.

Ljungqvist, A., and Wilhelm W.J., 2003. IPO Pricing in the Dot-Com Bubble, Journal of Finance. 58, 723-752.

Logue, D.E., 1973. On the Pricing of Unseasoned Equity Issues: 1965-1969. Journal of Financial and Quantitative Analysis. 8, 91-103.

Loughran, T. and Ritter J.R., 1995. The New Issue Puzzle, Journal of Finance. 50, 23-51.

Loughran, T. and Ritter J.R., 2002. Why Don't Issuers Get Upset About Leaving Money on the Table in IPOs? Review of Financial Studies. 15, 413-443.

Loughran, T. and Ritter J.R., 2004. Why Has IPO Underpricing Increased Over Time? Financial Management. 33, 5-37.

Lowry, M., Officer, M, and Schwert G.W., 2010, The Variability of IPO Initial Returns, Journal of Finance. 65(2), 425-465.

Lyn, E., O. and Zychowicz, E. J.2002. The performance of new equity offerings in Hungary and Poland. Global Finance Journal. 14(2) 181-195.

Lyon J., Barber B., and Tsai C., 1999. Improved methods for tests of long-run abnormal stock returns. Journal of Finance. 54, 165-201.

McDonald, J. and Fisher, A.K., 1972. New Issue Stock Price Behavior. Journal of Finance, 27, 97-102.

Megginson, W.L. and Weiss, K.A., 1991. Venture capitalist certification in initial public offerings. Journal of Finance. 46, 879-903.

Michaely, R., and Shaw W.H., 1994, The Pricing of Initial Public Offerings: Tests of Adverse- Selection and Signaling Theories, Review of Financial Studies. 7, 279-319.

Miller, R.E. and Reilly, F.K., 1987. An Examination of Mispricing, Returns and Uncertainty for Initial Public Offerings. Financial Management. 16, 33-38. 
Mok, H.M.K. and Hui, Y.V., 1998. Underpricing and the aftermarket performance of IPOs in Shanghai, China. Pacific-Basin Finance Journal. 6(5), 453-474.

Moshirian, F. ,Ng, D. and Wu, E., 2010. Model specification and IPO performance: New insights from Asia," Research in International Business and Finance. 24(1), 62-74.

Omran, M.,2005. Initial and Aftermarket Performance of Share Issue Privatization in the Egyptian Stock Market. Journal of Financial Research. 2, 215-234.

Page, M. and Reyneke, I., 1997. The timing and subsequent performance of initial public offerings (IPOs) on the Johannesburg Stock Exchange. Journal of Business, Finance and Accounting. 24, 1401-1420.

Paudyal. K., Saadouni, B., and Briston, R., 1998. Privatisation initial public offerings in Malaysia: Initial premium and long-term performance. Pacific-Basin Finance Journal. 6, 427-451.

Ravid, S. A., and M. Spiegel, 1997. Optimal financial contracts for a start-up with unlimited operating discretion, Journal of Financial and Quantitative Analysis. 32, 269286.

Reber, B, and Fong, C., 2006. Explaining Mispricing of Initial Public Offerings in Singapore. Applied Financial Economics. 16, 1339-1353.

Reilly, F.K. and Hatfield, K., 1969. Investor Experience with New Stock Issues. Financial Analyst Journal, 25, 73-80.

Ritter, J.R., 1984. The Hot Issue Market of 1980. Journal of Business. 57, 215-240.

Ritter, J.R., 1987. The Costs of Going Public. Journal of Financial Economics. 19, 269282

Ritter, J.R., 1991, The Long-Run Performance of Initial Public Offerings. Journal of Finance, 46, 3-27.

Ritter, J.R., 1998. Initial public offerings. Contemporary Finance Digest. 2(1), 5-30.

Ritter, J.R., and Welch I., 2002. A Review of IPO Activity, Pricing, and Allocations, Journal of Finance. 57, 1795-1828.

Rock, K., 1986. Why New Issues Are Underpriced. Journal of Financial Economics. 15, 187-212.

Samarakoon .L,P.,2010.The Short-Run Underpricing of Initial Public Offerings in the Sri Lankan Stock Market. Journal of Multinational Financial Management. 20,197-213. 
Titman, S. and Trueman. B., 1986. Information Quality and the Valuation of New Issues. Journal of Accounting and Economics. 8(2), 159-172.

Wasserfallen, W. and Wittleder, C., 1994. Pricing initial public offerings. European Economic Review. 38, 1505-1517.

Welch, I., 1989, Seasoned Offerings, Imitation Costs, and the Underpricing of Initial Public Offerings. Journal of Finance. 44, 421-449.

Welch, I., 1992. Sequential Sales, Learning and Cascades. Journal of Finance. 47, 695732 .

White, H., 1980. A heteroscedasticity-consistent covariance matrix estimator and a direct test for heteroscedasticity. Econometrica. 48 (4), 817-838 
TABLE 1: DESCRIPTION AND COMPUTATION OF EXPLANATORY VARIABLES USED IN THE STUDY OF SHORT-RUN UNDERPRICING

\begin{tabular}{|c|c|c|c|}
\hline $\begin{array}{l}\text { EXPLANATORY } \\
\text { VARIABLES }\end{array}$ & $\begin{array}{l}\text { EXPECTED } \\
\text { SIGN }\end{array}$ & DESCRIPTIONS & CALCULATION \\
\hline $\begin{array}{l}\mathrm{ROA}=\text { rate of return } \\
\text { on total assets }\end{array}$ & $-\mathrm{VE}$ & $\begin{array}{l}\text { A high return on assets is synonymous } \\
\text { with high profitability which alleviates } \\
\text { investors concerns and reduces } \\
\text { uncertainties such that lower average } \\
\text { underpricing is expected. }\end{array}$ & $\begin{array}{l}\text { The net income before the IPO divided by } \\
\text { total assets before listing. }\end{array}$ \\
\hline SIZE $=$ issue proceeds & $-\mathrm{VE}$ & $\begin{array}{l}\text { Smaller offerings tend to be more } \\
\text { speculative than larger offerings and as } \\
\text { such exhibit greater underpricing. }\end{array}$ & $\begin{array}{l}\text { The log of firm } i \text { 's offering size computed } \\
\text { as the total number of shares issued at the } \\
\text { offering times the offering price. }\end{array}$ \\
\hline $\mathrm{AGE}=$ age of the firm & $-\mathrm{VE}$ & $\begin{array}{l}\text { Older firms have lower ex-ante } \\
\text { uncertainty compared to younger firms } \\
\text { and as such are expected to be subject to } \\
\text { lower underpricing. }\end{array}$ & $\begin{array}{l}\text { The logarithm of one plus the company's } \\
\text { age in years, where age is calculated from } \\
\text { the year of incorporation to the year of } \\
\text { listing. }\end{array}$ \\
\hline $\begin{array}{l}\text { FINLEV }=\text { Financial } \\
\text { Leverage }\end{array}$ & $+\mathrm{VE}$ & $\begin{array}{l}\text { Financial leverage is used as a proxy for } \\
\text { the risks of the firm. Greater risks are } \\
\text { linked to greater underpricing. }\end{array}$ & $\begin{array}{l}\text { The book value of pre-IPO debt (short term } \\
\text { and long term) divided by the book value of } \\
\text { all assets. }\end{array}$ \\
\hline $\begin{array}{l}\text { RISK }=\text { Aftermarket } \\
\text { risk level of the IPO }\end{array}$ & $+\mathrm{VE}$ & $\begin{array}{l}\text { The more the price of the new company is } \\
\text { uncertain, the more discount an issuer } \\
\text { will offer in selling the IPO. }\end{array}$ & $\begin{array}{l}\text { Risk is defined as the Standard Deviation } \\
\text { (SD) of the returns after the listing of the } \\
\text { IPO over next thirty days. }\end{array}$ \\
\hline $\begin{array}{l}\text { ZSCORE = Ex-ante } \\
\text { Financial Strength }\end{array}$ & $-\mathrm{VE}$ & $\begin{array}{l}\text { IPOs with high financial strength should } \\
\text { be associated with lower underpricing due } \\
\text { to their lower ex-ante uncertainty. }\end{array}$ & $\begin{array}{l}\text { An Altman Z-score is calculated based on } \\
\text { figures prior to the year of listing to proxy } \\
\text { the ex-ante financial strength. }\end{array}$ \\
\hline $\begin{array}{l}\text { EPS = Earnings Per } \\
\text { Share }\end{array}$ & $+\mathrm{VE}$ & $\begin{array}{l}\text { There will be a large investor demand for } \\
\text { issues that have higher earnings per share } \\
\text { as this sends positive signals to the } \\
\text { market on the firm's profitability. }\end{array}$ & $\begin{array}{l}\text { Earnings per share are measured for the } \\
\text { most recent twelve months in the year prior } \\
\text { to going public. }\end{array}$ \\
\hline $\begin{array}{l}\text { SEO }=\text { Seasoned } \\
\text { Equity Offerings }\end{array}$ & $+\mathrm{VE}$ & $\begin{array}{l}\text { A higher price at a seasoned offering } \\
\text { (SEO) eventually compensates firms for } \\
\text { the intentionally low IPO price as firms } \\
\text { exercise patience to time their seasoned } \\
\text { offerings. }\end{array}$ & $\begin{array}{l}\text { A binary variable where a value of one } \\
\text { indicates the firm issues a SEO with the } \\
\text { definition being broadened to right issues. }\end{array}$ \\
\hline $\begin{array}{l}\text { BROKREP }=\text { Stock } \\
\text { broker's reputation }\end{array}$ & $-\mathrm{VE}$ & $\begin{array}{l}\text { Prestigious underwriters are associated } \\
\text { with a lower degree of underpricing since } \\
\text { they eliminate some uncertainties and } \\
\text { signal some favourable private } \\
\text { information. }\end{array}$ & $\begin{array}{l}\text { Sponsoring stockbroker reputation is } \\
\text { proxied by the number of issues the } \\
\text { stockbroker has sponsored. A dummy } \\
\text { variable is then used where a value of one } \\
\text { indicates that the firm has been sponsored } \\
\text { by a highly prestigious stock broker. }\end{array}$ \\
\hline $\begin{array}{l}\text { AUDITREP }= \\
\text { Auditor's Reputation }\end{array}$ & $-\mathrm{VE}$ & $\begin{array}{l}\text { The uncertainty surrounding the firm will } \\
\text { go down as reputation increases. In } \\
\text { particular, high quality audit firms will be } \\
\text { associated with lower underpricing. }\end{array}$ & $\begin{array}{l}\text { Auditor's reputation is calculated by taking } \\
\text { the ratio of the number of IPOs audited to } \\
\text { the total number of IPOs during the sample } \\
\text { period. A dummy variable is then used } \\
\text { where a value of one indicates that the firm } \\
\text { has been audited by a highly quality auditor. }\end{array}$ \\
\hline
\end{tabular}




\section{TABLE 2: DESCRIPTIVE STATISTICS ON AGGREGATE UNDERPRICING}

Descriptive Statistics for unadjusted and market adjusted measures of underpricing for 44 Mauritian newly listed companies from 1989 to 2005 . Given that all the returns are skewed (mean being greater than the median), we use the bootstrapped skewness-adjusted t-statistics developed by Lyon, Barber, and Tsai (1999).

\begin{tabular}{|c|c|c|c|c|c|c|c|}
\hline \multirow{2}{*}{\multicolumn{8}{|c|}{$\begin{array}{l}\mathrm{N}=44) \\
\text { First day returns (\%) }\end{array}$}} \\
\hline & & & & & & & \\
\hline $\begin{array}{ll}\text { INITIAL } & \text { RAW } \\
\text { RETURNS } & \end{array}$ & 0.00 & 108.33 & 14.29 & 5.63 & 0.00 & 9.08 & 22.60 \\
\hline $\begin{array}{ll}\text { MARKET } & \text { ADJUSTED } \\
\text { RETURNS } & \end{array}$ & -1.79 & 103.77 & 13.14 & 6.40 & 0.00 & 6.92 & 22.39 \\
\hline First week returns (\%) & & & & & & & \\
\hline $\begin{array}{ll}\text { INITIAL } & \text { RAW } \\
\text { RETURNS } & \end{array}$ & -2.94 & 113.00 & 17.70 & 7.06 & 0.00 & 10.00 & 22.95 \\
\hline $\begin{array}{ll}\text { MARKET } & \text { ADJUSTED } \\
\text { RETURNS } & \end{array}$ & -2.59 & 112.12 & 16.32 & 7.18 & 0.00 & 9.23 & 22.19 \\
\hline First month returns (\%) & & & & & & & \\
\hline $\begin{array}{l}\text { INITIALRAW } \\
\text { RETURNS }\end{array}$ & -17.17 & 149.00 & 20.62 & 6.15 & 0.00 & 16.46 & 29.25 \\
\hline $\begin{array}{ll}\text { MARKET } & \text { ADJUSTED } \\
\text { RETURNS } & \end{array}$ & -22.36 & 144.97 & 16.50 & 5.33 & 0.00 & 7.76 & 28.66 \\
\hline
\end{tabular}

TABLE 3: SIZE EFFECT AND AVERAGE UNDERPRICING

Distribution of market adjusted first day underpricing for 44 Mauritian newly listed companies from 1989 to 2005 based on their market capitalization. We used Rs 125 million, Rs 240 million and Rs 700 million as cut-offs as they are close to the first, median and third quartile values respectively. However, given the small sample size, firms are also partitioned (separately) into two groups (small and large) based on their market capitalization. The small group pertains to firms whose market capitalization values are less than Rs 240 million.

\begin{tabular}{|c|c|c|c|}
\hline Market Capitalization & $\begin{array}{l}\text { Number } \\
\text { of IPOs }\end{array}$ & $\begin{array}{l}\text { Average First day Raw } \\
\text { Underpricing }(\%)\end{array}$ & $\begin{array}{l}\text { Average First day Market } \\
\text { adjusted Underpricing (\%) }\end{array}$ \\
\hline$<\mathrm{Rs} 125 \mathrm{M}$ & 11 & 14.77 & 12.56 \\
\hline Rs 126 M-Rs $240 \mathrm{M}$ & 11 & 15.32 & 15.09 \\
\hline Rs $241 \mathrm{M}$ - Rs $700 \mathrm{M}$ & 11 & 9.96 & 8.50 \\
\hline$>$ Rs $700 \mathrm{M}$ & 11 & 16.63 & 15.80 \\
\hline Small & 22 & 15.74 & 14.51 \\
\hline Large & 22 & 12.85 & 11.76 \\
\hline $\begin{array}{l}\text { Wilcoxon Z-Value } \\
\text { (P-values in parentheses) }\end{array}$ & & $\begin{array}{r}-0.958 \\
(0.338)\end{array}$ & $\begin{array}{l}-0.406 \\
(0.685)\end{array}$ \\
\hline
\end{tabular}


TABLE 4: OFFER TYPE AND AVERAGE UNDERPRICING

Distribution of market adjusted first day underpricing for 44 Mauritian newly listed companies from 1989 to 2005 based on their types of offer. The NEW category stands for all firms which have issued new shares in the IPO market while the OLD category represents instances where no new shares are created.

\begin{tabular}{|c|c|c|c|}
\hline $\begin{array}{l}\text { UNDERPRICING } \\
\text { BY OFFER TYPE }\end{array}$ & Number of IPOs & $\begin{array}{l}\text { Average First day Raw } \\
\text { Underpricing }(\%)\end{array}$ & $\begin{array}{l}\text { Average First day Market } \\
\text { adjusted Underpricing (\%) }\end{array}$ \\
\hline NEW & 14 & 15.61 & 15.05 \\
\hline OLD & 30 & 13.68 & 12.24 \\
\hline ALL & 44 & 14.29 & 13.14 \\
\hline \multicolumn{2}{|c|}{$\begin{array}{l}\text { Wilcoxon Z-Value } \\
\text { (P-values in parentheses) }\end{array}$} & $\begin{array}{r}-0.419 \\
(0.675)\end{array}$ & $\begin{array}{r}-0.973 \\
(0.331)\end{array}$ \\
\hline
\end{tabular}

\section{TABLE 5: STOCKBROKER REPUTATION, AUDITOR REPUTATION AND AVERAGE UNDERPRICING}

Distribution of market adjusted first day underpricing for 44 Mauritian newly listed companies from 1989 to 2005 based on the stockbroker and auditor reputation. The sample is partitioned into two groups on the basis of stockbroker quality and auditor quality (HIGH and LOW). The Stockbroker's reputation is proxied by the number of issues which have been sponsored while the auditor's reputation is proxied by the number of listed firms which have been audited.

\begin{tabular}{|c|c|c|c|}
\hline \multicolumn{4}{|c|}{ UNDERPRICING BY STOCKBROKING COMPANIES REPUTATION } \\
\hline QUALITY & Number of IPOs & $\begin{array}{l}\text { Average First day } \\
\text { Raw Underpricing } \\
\text { (\%) }\end{array}$ & $\begin{array}{l}\text { Average First day } \\
\text { Market adjusted } \\
\text { Underpricing (\%) }\end{array}$ \\
\hline HIGH & 29 & 13.83 & 13.32 \\
\hline LOW & 15 & 15.20 & 12.78 \\
\hline \multicolumn{2}{|c|}{$\begin{array}{l}\text { Wilcoxon Z-Value } \\
\text { (P-values in parentheses) }\end{array}$} & $\begin{array}{l}-0.345 \\
(0.730)\end{array}$ & $\begin{array}{l}-1.079 \\
(0.281)\end{array}$ \\
\hline \multicolumn{4}{|c|}{ UNDERPRICING BY AUDITOR REPUTATION } \\
\hline QUALITY & Number of IPOs & $\begin{array}{l}\text { Average First day } \\
\text { Raw Underpricing } \\
\text { (\%) }\end{array}$ & $\begin{array}{l}\text { Average First day } \\
\text { Market adjusted } \\
\text { Underpricing (\%) } \\
\end{array}$ \\
\hline HIGH & 25 & 15.88 & 15.09 \\
\hline LOW & 19 & 12.21 & 10.57 \\
\hline \multicolumn{2}{|c|}{$\begin{array}{l}\text { Wilcoxon Z-Value } \\
\text { (P-values in parentheses) }\end{array}$} & $\begin{array}{r}2.093 \\
(0.036) \\
\end{array}$ & $\begin{array}{r}1.932 \\
(0.053)\end{array}$ \\
\hline
\end{tabular}

TABLE 6: FINANCIAL STRENGTH AND AVERAGE UNDERPRICING

Distribution of market adjusted first day underpricing for 44 Mauritian newly listed companies from 1989 to 2005 based on their financial strength proxied by the ALTMAN Z-score model. Based on Altman (2000), those firms having of a score less than 1.23 will be placed in the LOW financial health group. With regards to the return to risk ratio, the median value is used to partition firms into the high and low financial strength group.

\begin{tabular}{|c|c|c|c|}
\hline \multicolumn{4}{|c|}{ UNDERPRICING BY FINANCIAL STRENGTH- Altman Z Score } \\
\hline $\begin{array}{l}\text { FINANCIAL } \\
\text { STRENGTH }\end{array}$ & Number of IPOs & $\begin{array}{l}\text { Average First day Raw } \\
\text { Underpricing (\%) }\end{array}$ & $\begin{array}{l}\text { Average First day Market } \\
\text { adjusted Underpricing (\%) }\end{array}$ \\
\hline HIGH & 26 & 9.85 & 9.21 \\
\hline LOW & 18 & 17.37 & 15.86 \\
\hline \multicolumn{2}{|c|}{ Wilcoxon Z-Value (p-values in parentheses) } & $-3.193(0.016)$ & $-2.032(0.043)$ \\
\hline \multicolumn{4}{|c|}{ UNDERPRICING BY FINANCIAL STRENGTH- Return to Risk } \\
\hline $\begin{array}{l}\text { FINANCIAL } \\
\text { STRENGTH }\end{array}$ & Number of IPOs & $\begin{array}{l}\text { Average First day Raw } \\
\text { Underpricing }(\%)\end{array}$ & $\begin{array}{l}\text { Average First day Market } \\
\text { adjusted Underpricing }(\%)\end{array}$ \\
\hline HIGH & 22 & 9.26 & 8.09 \\
\hline LOW & 22 & 19.32 & 18.18 \\
\hline \multicolumn{2}{|c|}{ Wilcoxon Z-Value (p-values in parentheses) } & $-2.763(0.006)$ & $-2.497(0.013)$ \\
\hline
\end{tabular}


TABLE 7: INITIAL AND IMMEDIATE MARKET AVERAGE ABNORMAL RETURNS

The table below shows the initial and aftermarket returns on a daily basis over the 7-day window following the date of initial quotation on the exchange.

\begin{tabular}{|c|c|c|c|c|c|c|c|c|c|}
\hline & $\begin{array}{l}\text { Number } \\
\text { of firms }\end{array}$ & $\begin{array}{l}\text { Initial } \\
\text { Market } \\
\text { Adjusted } \\
\text { Average } \\
\text { Return } \\
(\%)\end{array}$ & Day 1 & Day 2 & Day 3 & Day 4 & Day 5 & Day 6 & Day 7 \\
\hline ALL FIRMS & 44 & 13.14 & 3.67 & 1.02 & 1.19 & 0.02 & -1.01 & -0.78 & -0.40 \\
\hline \multicolumn{10}{|c|}{ SEGMENTATION BY INDUSTRY } \\
\hline $\begin{array}{l}\text { BANKS AND } \\
\text { INSURANCE }\end{array}$ & 8 & 9.17 & 2.87 & 0.35 & -1.76 & -0.83 & -2.67 & -2.14 & -0.67 \\
\hline COMMERCE & 7 & 17.59 & 2.14 & 2.87 & 6.48 & 0.96 & -0.13 & 0.86 & 0.80 \\
\hline $\begin{array}{l}\text { HOTELS AND } \\
\text { LEISURE }\end{array}$ & 5 & 10.77 & 2.60 & -1.91 & -2.37 & -0.89 & -1.81 & -1.38 & -0.42 \\
\hline INDUSTRY & 7 & 12.97 & 4.49 & 0.73 & -0.73 & -1.31 & -1.64 & 0.99 & 1.15 \\
\hline INVESTMENT & 11 & 17.98 & 4.17 & 0.62 & 2.01 & 1.04 & -1.07 & -1.79 & -0.45 \\
\hline SUGAR & 5 & 4.12 & 3.09 & 1.03 & 0.63 & -0.57 & 1.50 & -0.06 & -3.38 \\
\hline TRANSPORT & 1 & 17.71 & 5.97 & 6.00 & 2.44 & -3.06 & -3.35 & -0.39 & 0.84 \\
\hline \multicolumn{10}{|c|}{ SEGMENTATION BY MARKET CAPITALISATION } \\
\hline SMALL & 22 & 14.51 & 4.82 & 1.71 & 2.32 & -0.01 & -1.02 & -0.70 & -0.90 \\
\hline LARGE & 22 & 11.76 & 2.02 & 0.00 & -0.39 & -0.40 & -1.27 & -0.67 & 0.21 \\
\hline \multicolumn{10}{|c|}{ SEGMENTATION BY GROSS PROCEEDS } \\
\hline SMALL & 22 & 15.87 & 3.34 & 0.84 & 0.18 & -0.59 & -0.17 & -0.18 & -1.04 \\
\hline LARGE & 22 & 10.41 & 3.43 & 0.83 & 1.72 & 0.19 & -2.17 & -1.22 & 0.40 \\
\hline \multicolumn{10}{|c|}{ SEGMENTATION BY OFFER TYPE } \\
\hline NEW & 14 & 15.05 & 1.34 & 0.02 & -0.12 & -0.20 & -1.25 & -0.34 & 0.43 \\
\hline OLD & 30 & 12.24 & 4.27 & 1.19 & 1.39 & -0.22 & -1.10 & -0.84 & -0.66 \\
\hline \multicolumn{10}{|c|}{ SEGMENTATION BY STOCKBORKER REPUTATION } \\
\hline HIGH & 29 & 13.32 & 3.07 & 0.86 & 1.29 & -0.20 & -1.12 & -1.18 & -0.01 \\
\hline LOW & 15 & 12.78 & 3.97 & 0.79 & 0.27 & -0.24 & -1.20 & 0.23 & -0.94 \\
\hline \multicolumn{10}{|c|}{ SEGMENTATION BY AUDITOR REPUTATION } \\
\hline HIGH & 25 & 15.09 & 4.51 & 2.03 & 2.98 & 0.30 & -0.60 & -1.15 & -0.95 \\
\hline LOW & 19 & 10.57 & 1.96 & -0.67 & -1.65 & -0.86 & -1.84 & -0.10 & 0.45 \\
\hline \multicolumn{10}{|c|}{ SEGMENTATION BY FINANCIAL STRENGTH } \\
\hline HIGH & 26 & 9.21 & 3.86 & 1.16 & 1.62 & -0.41 & $\begin{array}{l}-1.33 \\
\end{array}$ & 0.07 & 0.20 \\
\hline LOW & 18 & 15.86 & 2.73 & 0.38 & -0.02 & 0.07 & -0.90 & -1.74 & -1.08 \\
\hline
\end{tabular}


TABLE 8: Multiple Regression to Explain the Short Run Market Adjusted Underpricing of IPOs

The sample period takes into account 44 IPOs from 1989 until 2005. The dependent variable is the initial market adjusted return of companies and the independent variables are defined as follows: ROA=rate of return on total assets, SIZE=issue proceeds, $A G E=$ age of the firm, FINLEV=Financial Leverage, RISK= Aftermarket risk level of the IPO, ZSCORE= Altman's Z-score prior to listing, EPS= Earnings Per Share, SEO=Seasoned Equity Offerings, BROKREP= Stock broker's reputation and AUDITREP= Auditor's Reputation. Several specifications of the regression model are used based on the ex-ante uncertainty hypothesis, the signalling hypothesis and the underwriter reputation hypothesis. White's (1980) adjusted student t-statistics are used where appropriate and conventional p-values are reported below each estimate followed by bootstrap-generated p-values. $* * *, * *$, and $*$ indicate statistical significance at the $1 \%, 5 \%$, and $10 \%$ levels respectively.

\begin{tabular}{|c|c|c|c|c|c|}
\hline & Model 1 & Model 2 & Model 3 & Model 4 & Model 5 \\
\hline Variables & $\begin{array}{l}\text { Ex-ante } \\
\text { uncertainty } \\
\text { hypothesis }\end{array}$ & $\begin{array}{l}\text { Signalling } \\
\text { hypothesis }\end{array}$ & $\begin{array}{l}\text { Underwriter } \\
\text { reputation } \\
\text { hypothesis }\end{array}$ & All Variables & Final Model \\
\hline Intercept & 0.2482 & 0.1514 & 0.0497 & 0.0545 & $\begin{array}{l}-0.0950 \\
-090\end{array}$ \\
\hline $\mathrm{p}$-value & 0.5662 & $0.0016 * * *$ & 0.2552 & 0.9710 & 0.2243 \\
\hline boot p-value & 0.6178 & $0.0302 * *$ & 0.4260 & 0.4913 & 0.2844 \\
\hline ROA & -0.6146 & & & -0.3611 & \\
\hline p-value & 0.3162 & & & 0.7151 & \\
\hline boot p-value & 0.4915 & & & 0.4996 & \\
\hline SIZE & -0.0108 & & & 0.0062 & \\
\hline $\mathrm{p}$-value & 0.8021 & & & 0.7503 & \\
\hline boot $p$-value & 0.4487 & & & 0.5912 & \\
\hline AGE & -0.1953 & & & -0.1613 & \\
\hline $\mathrm{p}$-value & $0.0737 *$ & & & 0.1563 & \\
\hline boot p-value & 0.2615 & & & 0.2402 & \\
\hline FINLEV & -0.0007 & & & -0.0007 & \\
\hline $\mathrm{p}$-value & 0.6702 & & & 0.2981 & \\
\hline boot p-value & 0.4474 & & & 0.4739 & \\
\hline RISK & 10.8704 & & & 9.2606 & 6.4956 \\
\hline p-value & $0.0442 * *$ & & & $0.0433 * *$ & $0.0691 *$ \\
\hline boot p-value & 0.8501 & & & 0.8645 & 0.1396 \\
\hline ZSCORE & -0.0086 & -0.0032 & & -0.0067 & -0.0040 \\
\hline $\mathrm{p}$-value & $0.0050 * * *$ & $0.0656^{*}$ & & $0.0017 * * *$ & $0.0058 * * *$ \\
\hline boot $\mathrm{p}$-value & 0.2133 & $0.0812^{*}$ & & 0.2145 & $0.0127 * *$ \\
\hline EPS & & -0.0103 & & -0.0014 & \\
\hline p-value & & 0.2627 & & 0.5450 & \\
\hline boot p-value & & 0.1952 & & 0.4495 & \\
\hline SEO & & 0.0536 & & -0.0591 & \\
\hline p-value & & 0.5371 & & 0.7538 & \\
\hline boot p-value & & 0.6668 & & 0.4856 & \\
\hline BROKREP & & & -0.0203 & -0.0374 & \\
\hline $\mathrm{p}$-value & & & 0.7814 & 0.5402 & \\
\hline boot p-value & & & 0.4501 & 0.4539 & \\
\hline AUDITREP & & & 0.1672 & 0.1481 & 0.1245 \\
\hline p-value & & & $0.0046 * * *$ & $0.0265 * *$ & $0.0037 * * *$ \\
\hline boot p-value & & & $0.0134 * *$ & 0.6491 & $0.0148 * *$ \\
\hline Adjusted $\mathrm{R}^{2}$ & 0.2069 & 0.0310 & 0.0950 & 0.2690 & 0.1665 \\
\hline F-VALUE & 2.6086 & 0.4267 & 3.2576 & 2.2375 & 3.8631 \\
\hline Prob.(F) & $0.0365 * *$ & 0.7350 & $0.0486 * *$ & $0.0448 * *$ & $0.0162 * *$ \\
\hline White's test p-value (1980) & $0.0249 * *$ & 0.9633 & 0.1958 & $0.0826^{*}$ & $0.0591^{*}$ \\
\hline
\end{tabular}


TABLE 9: Multiple Regression to Explain the Short Run Performance of IPOs

The sample period takes into account 44 IPOs from 1989 until 2005. The dependent variable is the short run performance of IPOs. The independent variables are defined as follows: ROA=rate of return on total assets, SIZE=issue proceeds, AGE $=$ age of the firm, FINLEV=Financial Leverage, RISK= Aftermarket risk level of the IPO, ZSCORE= Altman's Z-score prior to listing, EPS= Earnings Per Share, SEO=Seasoned Equity Offerings, BROKREP $=$ Stock broker's reputation and AUDITREP= Auditor's Reputation. White's (1980) adjusted student t-statistics are used where appropriate and conventional p-values are reported below each estimate followed by bootstrap-adjusted p-values. $* * *, * *$, and * indicate statistical significance at the $1 \%, 5 \%$, and $10 \%$ levels respectively.

\begin{tabular}{|c|c|c|c|c|c|c|c|c|}
\hline Dependent Variable & $\begin{array}{l}\text { First Week } \\
\text { Returns }\end{array}$ & $\begin{array}{l}\text { First } \\
\text { Month } \\
\text { Returns }\end{array}$ & $\begin{array}{l}\text { First } \\
\text { Week } \\
\text { Market } \\
\text { Adjusted } \\
\text { Returns } \\
\end{array}$ & $\begin{array}{l}\text { First } \\
\text { Month } \\
\text { Market } \\
\text { Adjusted } \\
\text { Returns } \\
\end{array}$ & $\begin{array}{l}\text { First } \\
\text { Week } \\
\text { Returns }\end{array}$ & $\begin{array}{l}\text { First } \\
\text { Month } \\
\text { Returns }\end{array}$ & $\begin{array}{l}\text { First } \\
\text { Week } \\
\text { Market } \\
\text { Adjusted } \\
\text { Returns } \\
\end{array}$ & $\begin{array}{l}\text { First } \\
\text { Month } \\
\text { Market } \\
\text { Adjusted } \\
\text { Returns } \\
\end{array}$ \\
\hline & Model 1 & Model 2 & Model 3 & Model 4 & Model 5 & Model 6 & Model 7 & Model 8 \\
\hline $\begin{array}{l}\text { Independent } \\
\text { Variables }\end{array}$ & All Variables & $\begin{array}{l}\text { All } \\
\text { Variables }\end{array}$ & $\begin{array}{l}\text { All } \\
\text { Variables }\end{array}$ & $\begin{array}{l}\text { All } \\
\text { Variables }\end{array}$ & $\begin{array}{l}\text { Final } \\
\text { Model }\end{array}$ & $\begin{array}{l}\text { Final } \\
\text { Model }\end{array}$ & $\begin{array}{l}\text { Final } \\
\text { Model }\end{array}$ & $\begin{array}{l}\text { Final } \\
\text { Model }\end{array}$ \\
\hline Intercept & -0.0181 & 0.4252 & 0.1280 & 0.6031 & -0.1179 & -0.1072 & -0.0964 & -0.0817 \\
\hline p-value & 0.9692 & 0.3531 & 0.7586 & 0.1492 & $0.0682 *$ & 0.2164 & $0.0952 *$ & 0.3365 \\
\hline boot p-value & 0.4823 & 0.6189 & 0.5658 & 0.6259 & 0.1601 & 0.2611 & 0.1674 & 0.3206 \\
\hline ROA & 0.2148 & 0.5436 & 0.0762 & 0.1119 & & & & \\
\hline p-value & 0.6804 & 0.4528 & 0.8850 & 0.8723 & & & & \\
\hline boot p-value & 0.9158 & 0.9126 & 0.9558 & 0.9788 & & & & \\
\hline SIZE & 0.0136 & -0.0260 & 0.0007 & -0.0369 & & & & \\
\hline p-value & 0.7555 & 0.5251 & 0.9855 & 0.3200 & & & & \\
\hline boot p-value & 0.5799 & 0.4596 & 0.5011 & 0.4603 & & & & \\
\hline AGE & -0.1785 & -0.3075 & -0.1997 & -0.3644 & & & & \\
\hline p-value & 0.1390 & $0.0721^{*}$ & $0.0904 *$ & $0.0263^{* *}$ & & & & \\
\hline boot p-value & 0.2010 & 0.1260 & 0.1759 & 0.1039 & & & & \\
\hline FINLEV & -0.0007 & -0.0003 & -0.0006 & -0.0005 & & & & \\
\hline p-value & 0.5638 & 0.8234 & 0.6462 & 0.7263 & & & & \\
\hline boot p-value & 0.4713 & 0.4965 & 0.4795 & 0.4993 & & & & \\
\hline RISK & 12.3160 & 8.3288 & 10.9414 & 6.6730 & 9.3951 & 7.5235 & 7.9365 & 4.7071 \\
\hline p-value & $0.0064 * * *$ & $0.0873^{*}$ & $0.0052 * * *$ & 0.1458 & $0.0014 * * *$ & $0.0516^{*}$ & $0.0024 * * *$ & 0.2157 \\
\hline boot p-value & 0.8635 & 0.6582 & 0.7833 & 0.6163 & $0.0176^{* *}$ & 0.1088 & $0.0234 * * *$ & 0.2950 \\
\hline ZSCORE & -0.0092 & -0.0065 & -0.0085 & -0.0066 & -0.0044 & & -0.0038 & \\
\hline p-value & $0.0006^{* * *}$ & 0.0442 & $0.0007 * * *$ & $0.0367 * *$ & $0.0004 * * *$ & & $0.0010^{* * *}$ & \\
\hline boot p-value & 0.2321 & 0.3344 & 0.2672 & 0.3438 & $0.0019 * * *$ & & $0.0043^{* * *} *$ & \\
\hline EPS & -0.0019 & 0.0300 & 0.0038 & $0.0361^{* *}$ & & & & \\
\hline p-value & 0.9315 & 0.2963 & 0.8550 & 0.2292 & & & & \\
\hline boot p-value & 0.4869 & 0.5616 & 0.5010 & 0.5911 & & & & \\
\hline SEO & 0.0133 & 0.0408 & 0.0010 & -0.0270 & & & & \\
\hline p-value & 0.8391 & 0.6259 & 0.9878 & 0.7500 & & & & \\
\hline boot p-value & 0.9928 & 0.5056 & 0.9886 & 0.4810 & & & & \\
\hline BROKREP & -0.0947 & -0.1260 & -0.0960 & -0.0971 & & & & \\
\hline p-value & 0.2351 & 0.2116 & 0.2364 & 0.3195 & & & & \\
\hline boot p-value & 0.3620 & 0.3718 & 0.3435 & 0.4076 & & & & \\
\hline AUDITREP & 0.1595 & 0.2077 & 0.1507 & 0.1995 & 0.1142 & 0.2043 & 0.1184 & 0.2137 \\
\hline p-value & $0.0242 * *$ & $0.0137^{* *} *$ & $0.0282 * *$ & $0.0168^{* *}$ & $0.0122^{* *}$ & $0.0820^{*}$ & $0.0110^{* *} *$ & $0.0046^{* * *}$ \\
\hline boot p-value & 0.6197 & 0.5447 & 0.6003 & 0.5461 & $0.0406^{* *}$ & $0.0236^{* *}$ & $0.0038^{* *}$ & 0.0170 *** \\
\hline Adjusted $\mathrm{R}^{2}$ & 0.2804 & 0.2013 & 0.2664 & 0.2140 & 0.2524 & 0.2179 & 0.2130 & 0.1714 \\
\hline F-VALUE & 2.4420 & 1.9328 & 2.3438 & 2.0075 & 5.8385 & 6.9908 & 4.8797 & 5.4467 \\
\hline Prob.(F) & $0.0317 * *$ & $0.0844 *$ & $0.0383 * *$ & $0.0731^{*}$ & $0.0021^{* * *}$ & $0.0024 * * *$ & $0.0055^{* * *}$ & $0.0080 * * *$ \\
\hline White's test p-value (1980) & 0.1461 & 0.1121 & 0.1603 & $0.0867 *$ & 0.4295 & 0.5777 & 0.6113 & 0.5474 \\
\hline
\end{tabular}

